\title{
Intensification of North American Megadroughts through Surface and Dust Aerosol Forcing*
}

\author{
BENJAMIN I. COOK \\ NASA Goddard Institute for Space Studies, New York, and Lamont-Doherty Earth Observatory, Palisades, New York \\ RICHARD SEAGER \\ Lamont-Doherty Earth Observatory, Palisades, New York \\ Ron L. Miller \\ NASA Goddard Institute for Space Studies, and Department of Applied Physics and Applied Math, \\ Columbia University, New York, New York \\ JOSEPH A. MASON \\ University of Wisconsin-Madison, Madison, Wisconsin
}

(Manuscript received 29 December 2011, in final form 25 September 2012)

\begin{abstract}
Tree-ring-based reconstructions of the Palmer drought severity index (PDSI) indicate that, during the Medieval Climate Anomaly (MCA), the central plains of North America experienced recurrent periods of drought spanning decades or longer. These megadroughts had exceptional persistence compared to more recent events, but the causes remain uncertain. The authors conducted a suite of general circulation model experiments to test the impact of sea surface temperature (SST) and land surface forcing on the MCA megadroughts over the central plains. The land surface forcing is represented as a set of dune mobilization boundary conditions, derived from available geomorphological evidence and modeled as increased bare soil area and a dust aerosol source $\left(32^{\circ}-44^{\circ} \mathrm{N}, 105^{\circ}-95^{\circ} \mathrm{W}\right)$. In the experiments, cold tropical Pacific SST forcing suppresses precipitation over the central plains but cannot reproduce the overall drying or persistence seen in the PDSI reconstruction. Droughts in the scenario with dust aerosols, however, are amplified and have significantly longer persistence than in other model experiments, more closely matching the reconstructed PDSI. This additional drying occurs because the dust increases the shortwave planetary albedo, reducing energy inputs to the surface and boundary layer. The energy deficit increases atmospheric stability, inhibiting convection and reducing cloud cover and precipitation over the central plains. Results from this study provide the first model-based evidence that dust aerosol forcing and land surface changes could have contributed to the intensity and persistence of the central plains megadroughts, although uncertainties remain in the formulation of the boundary conditions and the future importance of these feedbacks.
\end{abstract}

\section{Introduction}

During the late Medieval Climate Anomaly (MCA), hydroclimate in western North America and the central

* Lamont-Doherty Earth Observatory Contribution Number 7692.

Corresponding author address: Benjamin I. Cook, NASA Goddard Institute for Space Studies, 2880 Broadway, New York, NY 10025. E-mail: benjamin.i.cook@nasa.gov plains was defined largely by episodic droughts that typically persisted for multiple decades or longer (Cook et al. 2004, 2007, 2010; Herweijer et al. 2007; Stahle et al. 2007; Woodhouse and Overpeck 1998). These droughts had significant ecological and societal consequences, causing major disruptions in regional civilizations (e.g., Benson et al. 2007a,b; Douglass 1929) and leading to widespread vegetation mortality and dune mobilization (Forman et al. 2001; Hanson et al. 2010; Miao et al. 2007). These so-called megadroughts are not only unprecedented in the instrumental record but are also 
largely absent in climate reconstructions of the last 500 years. With modern droughts already exacting significant societal costs (Cook et al. 2007), there is much interest in understanding the processes that drive the persistence of the MCA megadroughts and assessing the possibility of such droughts occurring in the future (Cook et al. 2010).

Investigations into the forcing of the megadroughts have focused primarily on the role of sea surface temperature (SST) forcing during the MCA, especially shifts in the tropical Pacific (Burgman et al. 2010; Seager et al. 2008a), the Atlantic (Oglesby et al. 2012), or both (Conroy et al. 2009a; Feng et al. 2008). Drought conditions in the southern United States and central plains regions are favored by cold phases of the El NiñoSouthern Oscillation (ENSO) (i.e., La Niña conditions) and warm SSTs in the tropical Atlantic (e.g., Kushnir et al. 2010; Nigam et al. 2011; Schubert et al. 2009; Seager et al. 2005), and there is evidence in the paleorecord for cooler tropical Pacific SSTs during much of the MCA (Cobb et al. 2003; Conroy et al. 2009b). More recently, Graham et al. (2011) have suggested that an anomalously warm Indian Ocean and enhanced zonal SST gradient across the Indo-Pacific region may have also contributed to the megadroughts and other climate anomalies during the MCA. General circulation models (GCM), forced by either idealized (Feng et al. 2008) or reconstructed (Burgman et al. 2010; Seager et al. 2008a) SST fields, can stimulate some drying over North America but still have difficulty reproducing the magnitude and persistence of the MCA megadroughts.

Aside from remote SST-forced teleconnections, land surface feedbacks also play a critical role in modulating drought and hydroclimatic variability over North America. For example, the central plains has long been considered a "hot spot" for positive soil moistureprecipitation feedbacks (e.g., Findell et al. 2011; Koster et al. 2004; Meng and Quiring 2010). More recently, work on the Dust Bowl drought of the 1930s demonstrated that land degradation, in the form of vegetation mortality, wind erosion, and dust aerosols, could amplify regional drought over the central plains when these processes were included in a suite of climate model experiments (Cook et al. 2008, 2009). Specifically, these two studies found that dust aerosols and reduced vegetation cover caused significant warming and drying, increasing the fidelity of their simulated Dust Bowl temperature and precipitation anomalies. The warming was driven by increases in the Bowen ratio, as reduced vegetative cover caused significant declines in evapotranspiration, shifting the surface energy balance to favor sensible over latent heating. Dust aerosols suppressed precipitation via the well-established "Charney" mechanism (Charney 1975;
Charney et al. 1977), increasing the albedo and shortwave reflectance and reducing net radiative fluxes at the surface and top of the atmosphere. With less energy available to drive vertical movement of the atmosphere, convection, and precipitation were subsequently reduced. These feedbacks may be especially important to consider for the MCA megadroughts that occurred over the central plains, given the large-scale vegetation mortality, wind erosion, and dust aerosol transport that occurred during this interval, as inferred from records of paleo dunes (Forman et al. 2001; Hanson et al. 2010; Miao et al. 2007).

To date, however, the impact of the dune mobilization, vegetation mortality, and dust aerosols on the MCA megadroughts is understudied. While several papers have speculated that these landscape changes may have amplified these droughts (Feng et al. 2008; Seager et al. 2008b), only one study to date has explicitly tested surface impacts on the megadroughts within a modeling framework (Cook et al. 2011). They found that vegetation mortality alone (i.e., without wind erosion or dust feedbacks) was insufficient to amplify the modelsimulated droughts or reproduce the drought persistence seen in the paleorecord. Here, we expand on the experiments of Cook et al. (2011), presenting a new ensemble of simulations including wind erosion and dust aerosol forcing. We frame our analysis around two questions: 1) can forcing from dune mobilization, conceptualized as reduced vegetation coverage and a dust aerosol source, intensify simulated megadroughts over the central plains and 2) does inclusion of these surface factors increase the simulated persistence of these megadroughts?

\section{Methods and data}

\section{a. North American Drought Atlas}

We use information on drought history in North America from the North American Drought Atlas (NADA) version 2a (Cook et al. 2004, 2007), a gridded $\left(2.5^{\circ} \times 2.5^{\circ}\right)$ tree-ring-based reconstruction of the Palmer drought severity index (PDSI) (Palmer 1965) for boreal summer [June-August (JJA)]. The PDSI is a locally normalized index of drought that incorporates both moisture supply (precipitation) and demand (evaporation as a function of temperature) in its calculation. Positive values of the PDSI indicate wetter than normal conditions and negative values indicate drier than normal conditions. Despite the JJA focus of the NADA, PDSI has a memory time scale of about 12-18 months (Guttman 1998; Vicente-Serrano et al. 2010), allowing it to incorporate information on temperature and precipitation throughout the year. PDSI from the NADA has 
been used with good success to validate and inform a variety of modeling studies investigating historical and paleo-droughts over North America (e.g., Cook et al. 2011; Herweijer et al. 2006, 2007; Oglesby et al. 2012; Seager et al. 2008a).

\section{b. Model description}

For our experiments, we used a version of the Goddard Institute for Space Studies (GISS) atmospheric GCM "ModelE" (Schmidt et al. 2006), extensively updated in preparation for experiments as part of the Fifth Assessment Report of the Intergovernmental Panel on Climate Change (G. A. Schmidt et al. 2013, unpublished manuscript). This current version has a horizontal resolution of $2^{\circ} \times 2.5^{\circ}$ latitude/longitude with 40 vertical layers in the atmosphere. Each land cell is divided into vegetated and bare soil columns with six vertical layers that extend to a maximum depth of $3.5 \mathrm{~m}$ (heat and moisture budgets are calculated separately for each soil column). Vegetation is prescribed using Matthews (1983), and photosynthesis and stomatal conductance parameterizations are based on Farquhar et al. (1980) and Ball et al. (1987), respectively. Included within ModelE is a mineral dust aerosol model (Miller et al. 2006). In the default setup, dust aerosols are emitted to the atmosphere as a function of soil moisture and wind speed from regions identified by the source map of Ginoux et al. (2001), representing sediment filled topographic depressions that persist over geologic time scales. Once airborne, dust aerosols alter the radiative budget within the atmosphere, increasing shortwave reflection and longwave absorption. In the current version of the model, dust aerosols have no microphysical interactions. Studies using the immediately preceding Fourth Assessment Report version of the model have demonstrated the ability of ModelE to produce highfidelity simulations of the modern-day climate, including historical trends and variability (Hansen et al. 2007; Schmidt et al. 2006). Over North America, SST teleconnections are well resolved, and a variety of studies have successfully used ModelE to investigate twentieth-century hydroclimate variability over this region (e.g., Cook et al. 2008, 2009; Ruiz-Barradas and Nigam 2006).

\section{c. Boundary conditions}

For our historical ensemble (1857-2005 CE, described below), we used SST forcing from the Kaplan et al. (1998) dataset. For our MCA ensembles (1321-1461 $\mathrm{CE})$, the SST forcing was prescribed using a coral-based SST reconstruction for the tropical Pacific $\left(30^{\circ} \mathrm{S}-30^{\circ} \mathrm{N}\right)$ (Cobb et al. 2003). Oxygen isotope anomalies for the MCA portion of the Cobb et al. coral record were (a)

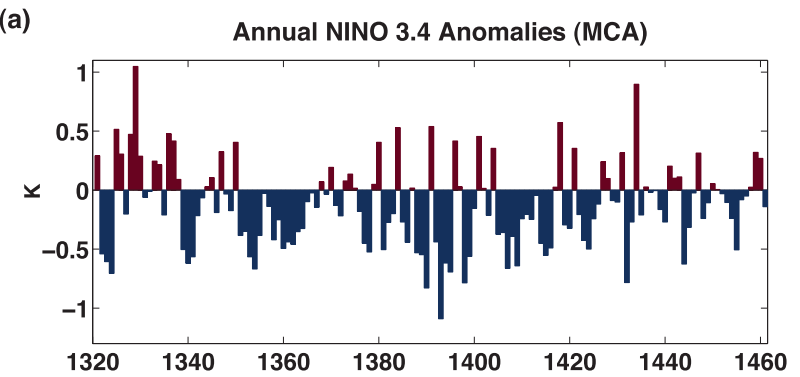

(b)

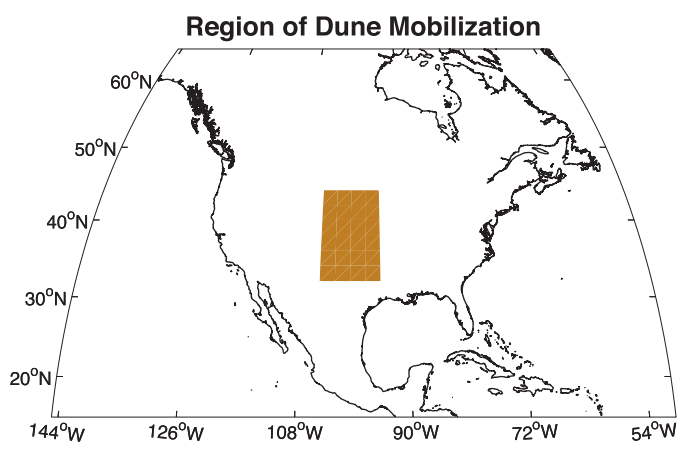

FIG. 1. (a) Niño-3.4 SST anomalies and (b) dune mobilization region $\left(32^{\circ}-44^{\circ} \mathrm{N}, 105^{\circ}-95^{\circ} \mathrm{W}\right)$ for the Medieval Climate Anomaly experiments. All MCA experiments (SST-Only, SST+BSOIL, and SST+BSOIL+DUST) use the same SST forcing, based on a coral reconstruction of SSTs in the tropical Pacific. Anomalies are relative to the 1856-2005 mean SSTs in the Niño-3.4 region from the Kaplan SST dataset. Dune mobilization region is used to define the $50 \%$ bare soil area in the SST+BSOIL and SST+BSOIL+DUST experiments and the dust source region in the SST+BSOIL+DUST experiment.

calculated relative to the monthly climatology for 1886$1998 \mathrm{CE}$ and converted to SST anomalies for low ( $\geq 6 \mathrm{yr}$ ) and high $(<6 \mathrm{yr})$ frequency components of the record separately, based on regressions against the Kaplan et al. dataset. Outside the tropical Pacific, SSTs were taken from the model runs of Seager et al. (2008a). In their experiments, Seager et al. (2008a) prescribed the Cobb et al. (2003) reconstruction in the tropical Pacific, coupling these SSTs elsewhere to a thermodynamic mixed layer ocean. SSTs outside the tropical Pacific therefore reflect the influence of tropical Pacific variability communicated primarily through atmospheric teleconnections. Annual SST anomalies in the Niño-3.4 region, calculated relative to the 1857-2005 CE mean from Kaplan et al. (1998), indicate a cooler than normal ENSO state during the late MCA (Fig. 1a). The tropical Pacific SSTs and ENSO variability reconstructed from the Cobb et al. (2003) coral records are generally supported by independent evidence for anomalously warm SSTs in the western tropical Pacific (Newton et al. 2006) and cool SSTs in the eastern tropical Pacific (Conroy et al. 2009b; Graham et al. 2007; Seager et al. 2007a) 
TABLE 1. Summary of model experiments conducted as part of this study. All experiments represent five-member ensembles, with each ensemble initialized using a unique set of starting conditions. For each simulation, the table indicates the years over which the ensembles were run, the source of the SST forcing, and if bare soil (BSOIL) or dust source (DUST) boundary conditions were included.

\begin{tabular}{|c|c|c|c|c|}
\hline Expt & Years & SSTs & Dune, bare soil & Dune, dust \\
\hline SST-MOD & $1857-2005$ & Kaplan et al. 1998 & - & - \\
\hline SST-Only & $1321-1461$ & Cobb et al. 2003 & - & - \\
\hline SST+BSOIL & $1321-1461$ & Cobb et al. 2003 & + & - \\
\hline SST+BSOIL+DUST & $1321-1461$ & Cobb et al. 2003 & + & + \\
\hline
\end{tabular}

during the MCA. Indirect evidence from regional hydroclimate records during the MCA also supports such a SST pattern (e.g., Graham et al. 2007, 2011; Seager et al. 2007a). However, some regional proxies indicate hydroclimate anomalies during the MCA that may be inconsistent with La Niña-like conditions (Moy et al. 2002; Thompson et al. 1984), suggesting remaining uncertainty in our understanding of tropical SSTs during the MCA. Further information and the details of the SST reconstruction and calculation can be found in Seager et al. (2008a), Burgman et al. (2010), and the supplemental material of Cook et al. (2011).

The geologic record provides evidence for widespread and recurrent dune mobilization events during the MCA (Forman et al. 2001; Hanson et al. 2010; Miao et al. 2007), with the most recent events likely occurring during the fourteenth and fifteenth centuries. These events were driven primarily by megadrought-induced vegetation mortality and reductions in vegetation cover. In the Nebraska Sand Hills, stratigraphic evidence shows that aeolian sand mobilization coincided with water table drawdown during the MCA (Mason et al. 2004). More generally, moisture availability for vegetation is likely to be the predominant control on dune mobility in the central plains. The sand-transporting potential of modern winds is high by global standards, but the dunes are largely stable at present because precipitation is sufficient to maintain vegetation cover (Muhs and Maat 1993). Large uncertainties remain, however, regarding the specific timing, duration, and extent of the vegetation mortality and associated wind erosion and dust aerosol forcing, making it difficult to develop quantitative boundary forcings for our model experiments. The fractional area of reduced vegetation cover in our model experiments should therefore be viewed primarily as a sensitivity test, and not as an attempt at fully reconstructing the actual area of vegetation mortality. For our MCA runs, we prescribed our dune mobilization region (Fig. 1b) over the central plains $\left(32^{\circ}-44^{\circ} \mathrm{N}, 105^{\circ}-95^{\circ} \mathrm{W}\right)$, based qualitatively on maps and evidence from geomorphological analyses (Forman et al. 2001; Hanson et al. 2010; Miao et al. 2007). For the model, we translated this to 1) a $50 \%$ reduction in vegetation cover (simulating the vegetation mortality) and 2) a new dust aerosol emission source coincident with the region of reduced vegetation cover and added to the default source map of Ginoux et al. (2001).

To validate wind erosion and dust aerosol emissions from this new source, we estimated aeolian deposition in two areas: $40^{\circ}-42^{\circ} \mathrm{N}, 98^{\circ}-100^{\circ} \mathrm{W}$ (area 1) and $40^{\circ}-42^{\circ} \mathrm{N}, 96^{\circ}-98^{\circ} \mathrm{W}$ (area 2). Application of optically stimulated luminescence dating to thick source-proximal loess sections with high resolution has demonstrated that major intervals of rapid Holocene loess accumulation were synchronous across the central plains (Miao et al. 2007). A discrete increment of loess deposited between 1100 and $1400 \mathrm{CE}$ is consistently present, forming about $5 \%-13 \%$ of the total Holocene loess thickness. Thinner Holocene loess forms a relatively uniform mantle over uplands in the areas chosen for validation [30-60 cm thick in area 1 and $24-36 \mathrm{~cm}$ thick in area 2, based on observations by Jacobs and Mason (2007) and soil surveys], allowing estimation of deposition rates at spatial scales comparable to model resolution. We assumed that the loess in those areas was preserved with minimal resuspension after deposition. Taking into account the ranges of total thickness and assuming $5 \%-13 \%$ of that total was deposited between 1100 and $1400 \mathrm{CE}$, we derived average aeolian deposition rates over the period 1100-1400 CE of 80380 and $60-230 \mathrm{~g} \mathrm{~m}^{-2} \mathrm{yr}^{-1}$ for areas 1 and 2, respectively. We used these deposition rates to validate the dust emissions from the new central plains source in our model scenario. We note, however, that, because of the paucity of available data on dust emissions and atmospheric loadings, there are still large uncertainties in the timing, provenance, and spatial extent of the wind erosion during the MCA. Our validation of the dust fluxes therefore represents a first attempt at reproducing MCA dust forcing in the model. Additionally, because of time uncertainties in our boundary conditions, including the SST reconstruction, we cannot directly compare our simulated droughts against specific drought events in the record. Instead, we compare our simulated droughts (1321-1461 CE) against general drought statistics from 

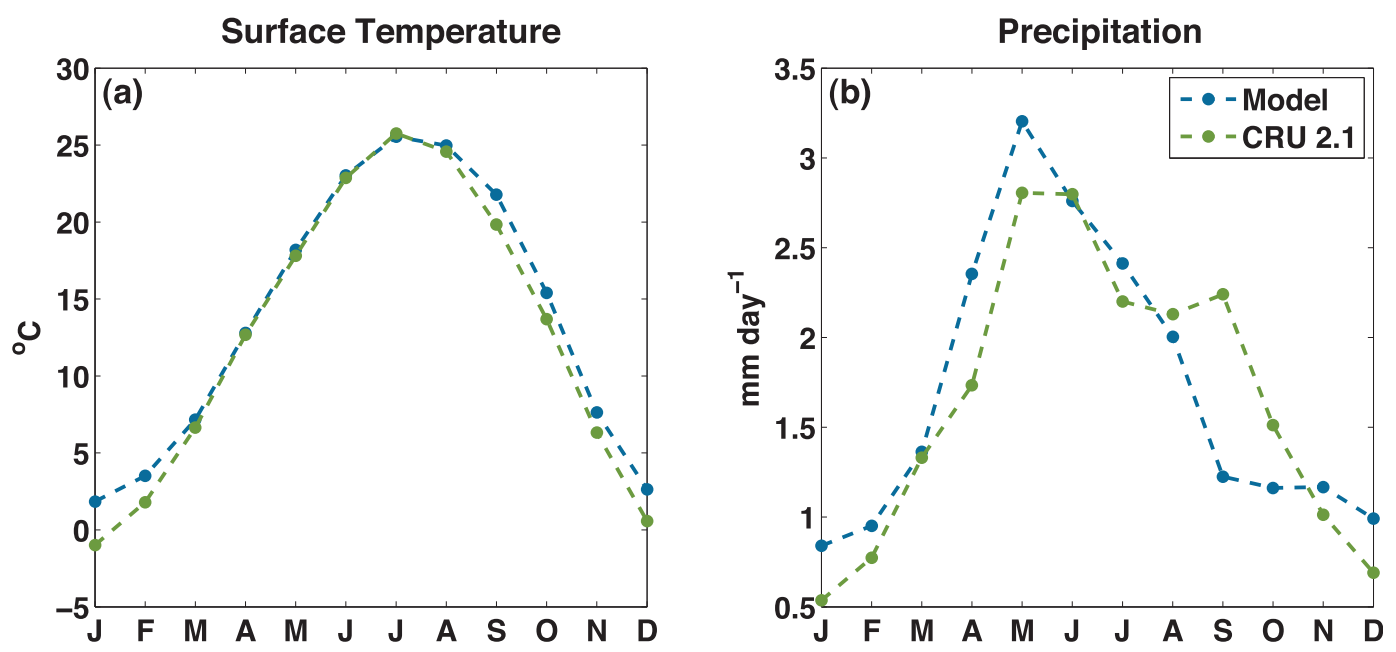

FIG. 2. Monthly (a) temperature and (b) precipitation climatology (1961-90) for the central plains region $\left(32^{\circ}-44^{\circ} \mathrm{N}\right.$, $105^{\circ}-95^{\circ} \mathrm{W}$ ), calculated from our modern-day SST-forced ensemble and the CRU 2.1 climate grids (green line).

the NADA for the MCA (1100-1500 CE) and the postMCA (1501-2000 CE) periods.

\section{d. Model experiments}

Our experiments comprise four 5-member ensemble simulations using ModelE (Table 1). Each experiment is based on a set of unique forcing, land surface, and SST boundary conditions, and each ensemble member is initialized using different initial states for the atmosphere and land surface. Our base run is SST-MOD, a historical (1857-2005 CE) control run forced with observational period solar (Wang et al. 2005), volcanic
(Hansen et al. 2002; Sato et al. 1993), and greenhouse gas forcings (Hansen and Sato 2004), as well as SSTs prescribed according to Kaplan et al. (1998). Unless otherwise indicated, all anomalies for the MCA model ensembles are calculated relative to the ensemble mean for 1857-2005 CE from SST-MOD. All MCA model ensembles are forced with transient, reconstructed estimates of forcing from greenhouse gas concentrations (Schmidt et al. 2011), solar variability (Delaygue and Bard 2011), and the reconstructed tropical Pacific SSTs from 1321 to 1461 CE. In SST-Only, we use the default land surface and MCA SST forcing only.
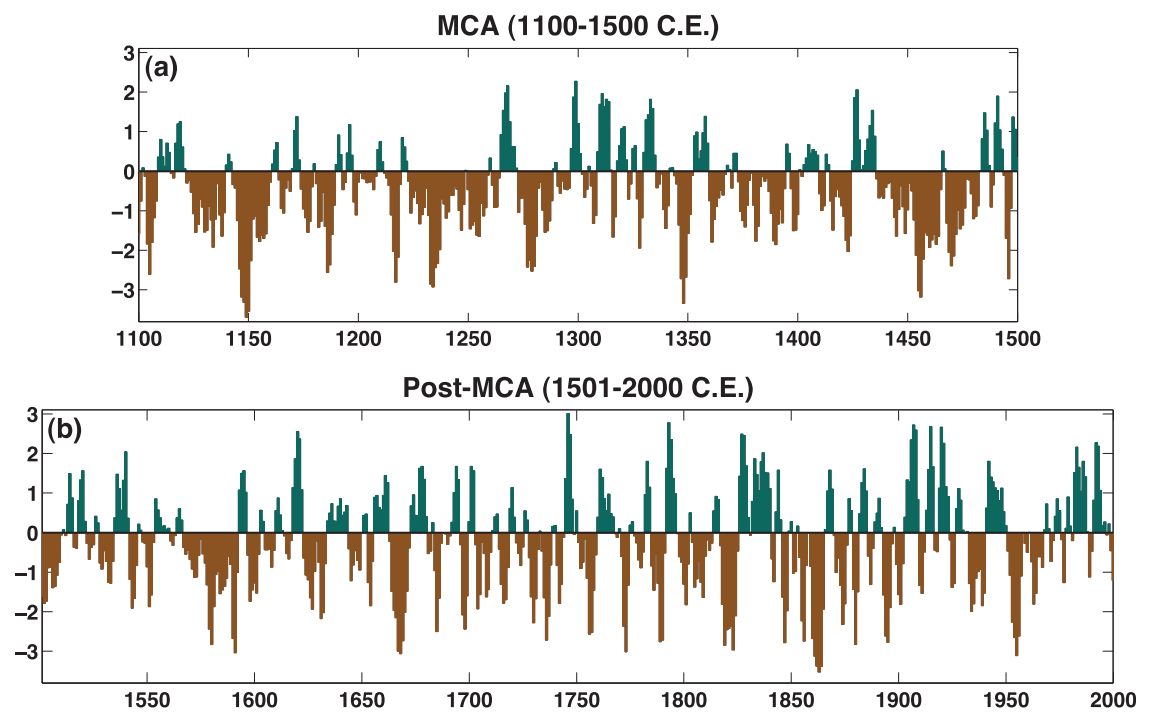

FIG. 3. Summer season (JJA) PDSI anomalies from the North American Drought Atlas (NADA), averaged over the central plains region $\left(32^{\circ}-44^{\circ} \mathrm{N}, 105^{\circ}-95^{\circ} \mathrm{W}\right)$. Droughts in this region (a) during the late Medieval Climate Anomaly (MCA) were generally more persistent than (b) droughts after $1500 \mathrm{CE}$. Both time series were smoothed with a 5-yr low-pass (lowess spline) filter. 

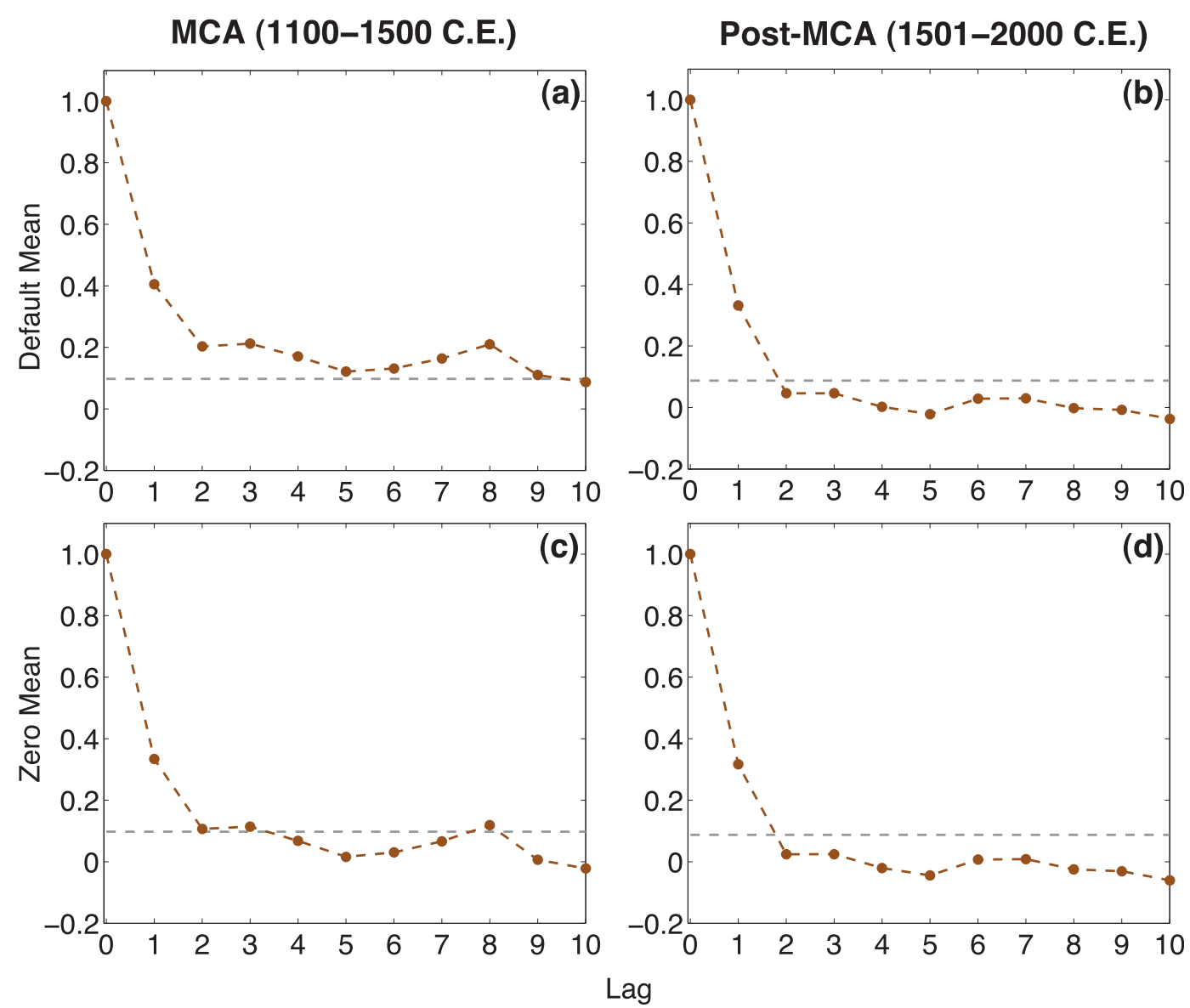

FIG. 4. Autocorrelation function (ACF) for central plains PDSI from the NADA. (a) Droughts during the MCA have significant persistence (gray line, $p \leq 0.05$ ) out to a lag of $9 \mathrm{yr}$. (b) Post-MCA drought persistence is significantly reduced, with significant persistence only at a lag of $1 \mathrm{yr}$. Even after standardizing to zero mean, (c) the MCA PDSI retains significant persistence at lags of $1,2,3$, and $8 \mathrm{yr}$, while (d) the post-MCA PDSI is relatively unchanged.

In SST+BSOIL, we use the MCA SST forcing and our $50 \%$ bare soil boundary condition over the central plains but with no central plains dust aerosol source, following Cook et al. (2011). Our final full-effect ensemble, SST + BSOIL + DUST, includes the SST forcing, central plains bare soil, and the new central plains dust source. We focus the bulk of our model and paleoclimate analyses on the central plains region where we prescribed the MCA land surface boundary conditions (i.e., the bare soil fraction and dust source). All significance testing is based on a two-sided Student's $t$ test with a significance threshold of $p \leq 0.05$.

\section{Results}

\section{a. Model validation}

For the central plains region, we compare the monthly climatology (1961-90 CE) of temperature and precipitation from the ensemble mean of our SST-MOD experiment against observations (1961-90 CE) from the Climate Research Unit (CRU) climate grids version 2.1 (Mitchell and Jones 2005) (Fig. 2). ModelE reproduces the amplitude and seasonality of climate over this region, including the seasonal peak in precipitation during the late spring and early summer (MayAugust). Major biases only occur in two months: April (positive) and September (negative).

Ensemble average annual average dust deposition from the SST+BSOIL+DUST experiment is $152( \pm 35$ std dev) and $82( \pm 19 \mathrm{std} \mathrm{dev}) \mathrm{g} \mathrm{m}^{-2} \mathrm{yr}^{-1}$ for areas 1 and 2, respectively. This places our dust source emissions at the low end of our observed range but within the same order of magnitude, suggesting that the simulated climate impact of dust in our SST+BSOIL+DUST ensemble is conservative. Given the uncertainties inherent in estimating these boundary conditions, we consider this a reasonable first-order estimate of the dust forcing during the MCA. 


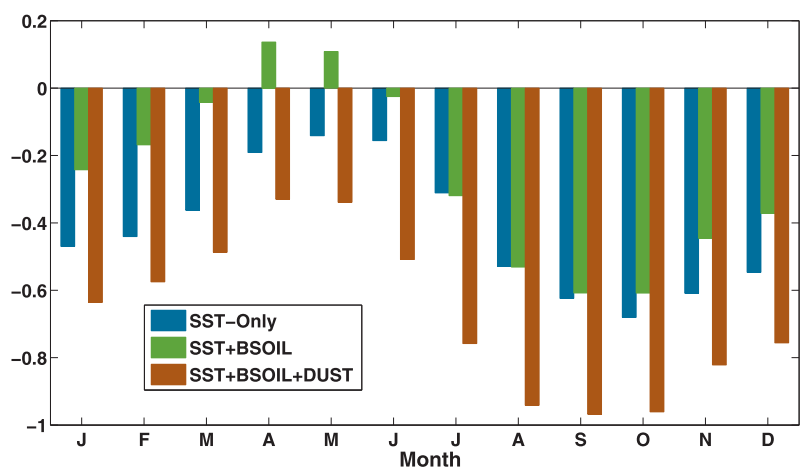

FIG. 5. Ensemble mean monthly PDSI over the central plains region $\left(32^{\circ}-44^{\circ} \mathrm{N}, 105^{\circ}-95^{\circ} \mathrm{W}\right)$ in our SST-Only (blue bars), SST + BSOIL (green bars), and SST + BSOIL+DUST (brown bars) experiments, relative to SST-MOD.

\section{b. PDSI in the North American Drought Atlas}

During the MCA (Fig. 3a), the central plains experienced multiple decadal or longer periods of drought that were largely absent in the post-MCA time period (Fig. 3b). This persistence is clearly seen in the autocorrelation of the PDSI calculated in the NADA, which shows significant autocorrelation of the MCA PDSI out to lags of $9 \mathrm{yr}$ (Fig. 4a). In contrast, persistence in the post-MCA PDSI is significant only at a lag of $1 \mathrm{yr}$ (Fig. 4b). To remove the impact of changes in the mean PDSI on the persistence calculation, we recalculated the autocorrelation functions for the MCA (Fig. 4c) and post-MCA PDSI (Fig. 4d) after adjusting the means of both time series to zero. Even with this adjustment, MCA PDSI retains significant persistence at time lags of $1,2,3$, and $8 \mathrm{yr}$, supporting the contention that, relative to recent periods, droughts during the MCA were largely unprecedented in their duration and persistence.

\section{c. PDSI in the MCA model simulations}

To evaluate the drought response in our MCA simulations and to facilitate comparisons with the NADA, we calculated PDSI using model surface temperature and precipitation. We calculated the PDSI for every grid cell over the central plains region separately, standardizing against the normal period defined by our SSTMOD ensemble (1857-2005) and then averaging over the central plains. Soil moisture capacity for the top and bottom layers was set to $25.4 \mathrm{~mm}$ (1 in.) and $127 \mathrm{~mm}$ (5 in.). Evapotranspiration was calculated as a function of temperature based on Thornthwaite (1948), the same method used to derive the PDSI that forms the foundation of the NADA reconstruction.

Averaged across all five ensemble members and all simulation years (1321-1461 CE), the three MCA
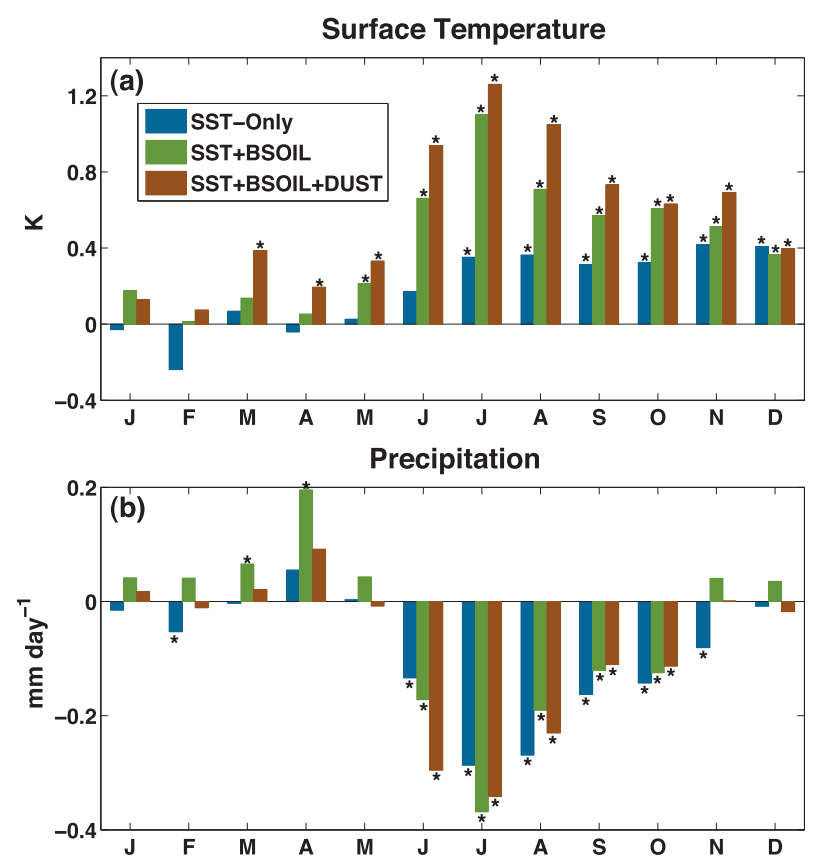

FIG. 6. (a) Ensemble mean monthly temperature (K) and (b) precipitation $\left(\mathrm{mm} \mathrm{day}^{-1}\right)$ anomalies over the central plains region $\left(32^{\circ}-44^{\circ} \mathrm{N}, 105^{\circ}-95^{\circ} \mathrm{W}\right)$, in our SST-Only (blue bars), SST + BSOIL (green bars), and SST+BSOIL+DUST (brown bars) experiments, relative to SST-MOD. Anomalies significantly different from SSTMOD (two-sided Student's $t$ test; $p \leq 0.05$ ) are indicated with an asterisk.

simulations show enhanced drought (negative PDSI) relative to the SST-MOD historical scenario (Fig. 5). The drying in all three simulations is generally largest during the summer months (June-September) and lowest during spring (April-May). The SST-Only and SST + BSOIL scenarios simulate similar levels of drying, except during winter and spring (January-May) when the magnitude of the negative PDSI anomalies in the SST+BSOIL scenario are reduced or, in the case of April-May, actually positive. With the addition of dust aerosols in SST+BSOIL+DUST, the drought intensity is amplified beyond SST-Only and SST+BSOIL, especially during the warm season. Averaged across JJA, the same season for which PDSI data are available from the NADA, the ensemble average PDSI values from the MCA runs are -0.33 (SST-Only), -0.30 (SST+BSOIL), and -0.74 (SST+BSOIL+DUST). The NADA, by comparison, has an average value during the MCA (1100-1500 CE) of -0.52 . From these simulations, dust aerosol forcing appears to be necessary in order to amplify plains drought beyond the SST forcing during the MCA, while increased bare soil area is unable, by itself, to contribute additional drought forcing [consistent with results from Cook et al. (2011)]. 


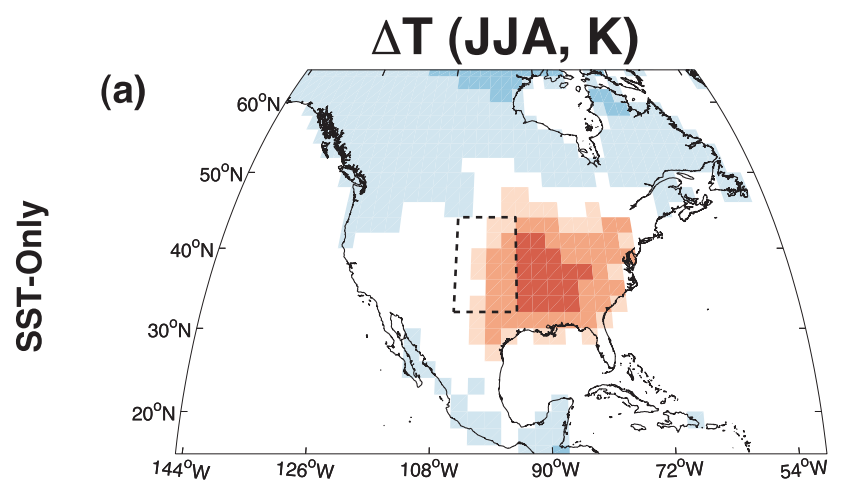

(b)
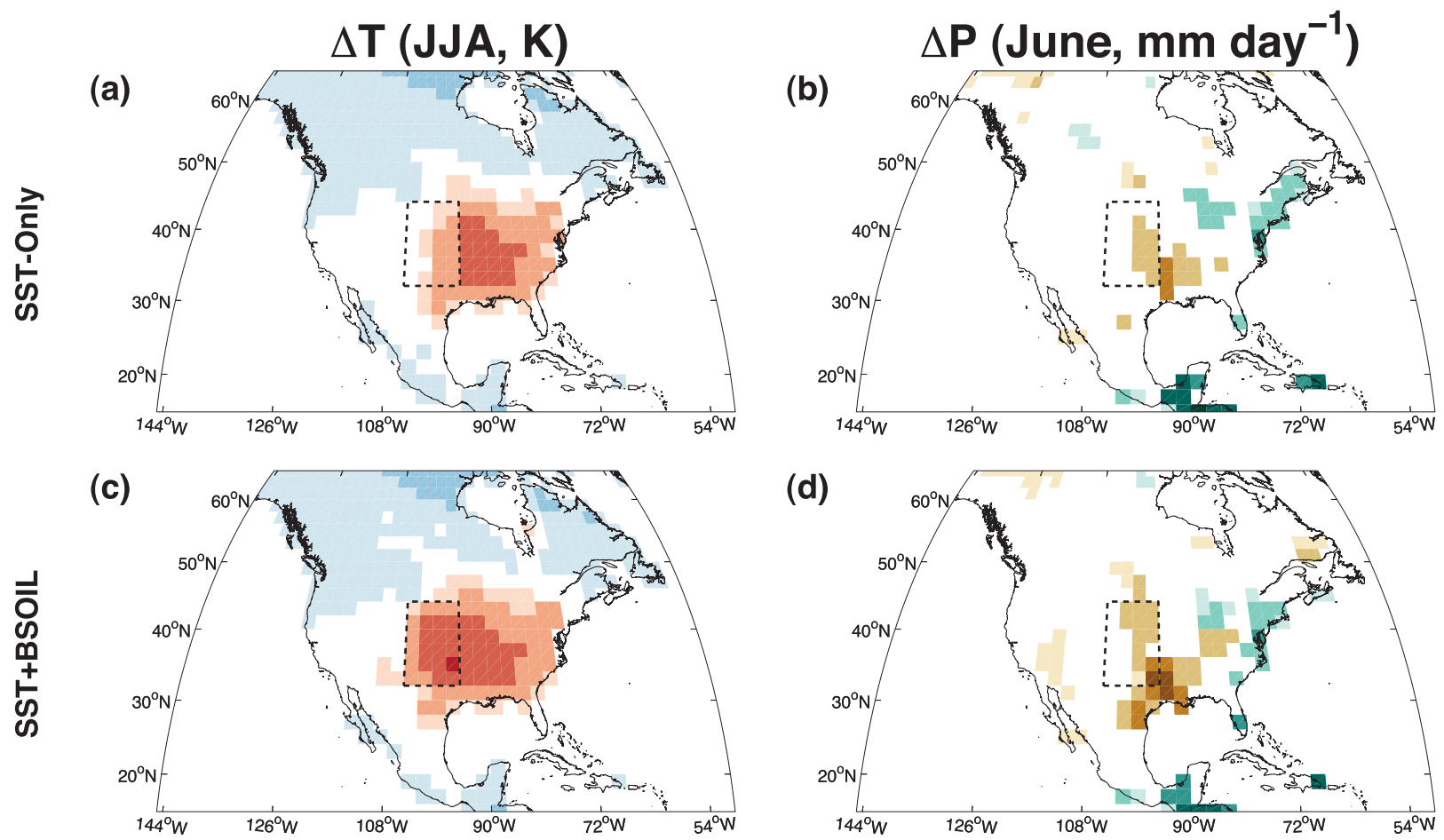

(d)
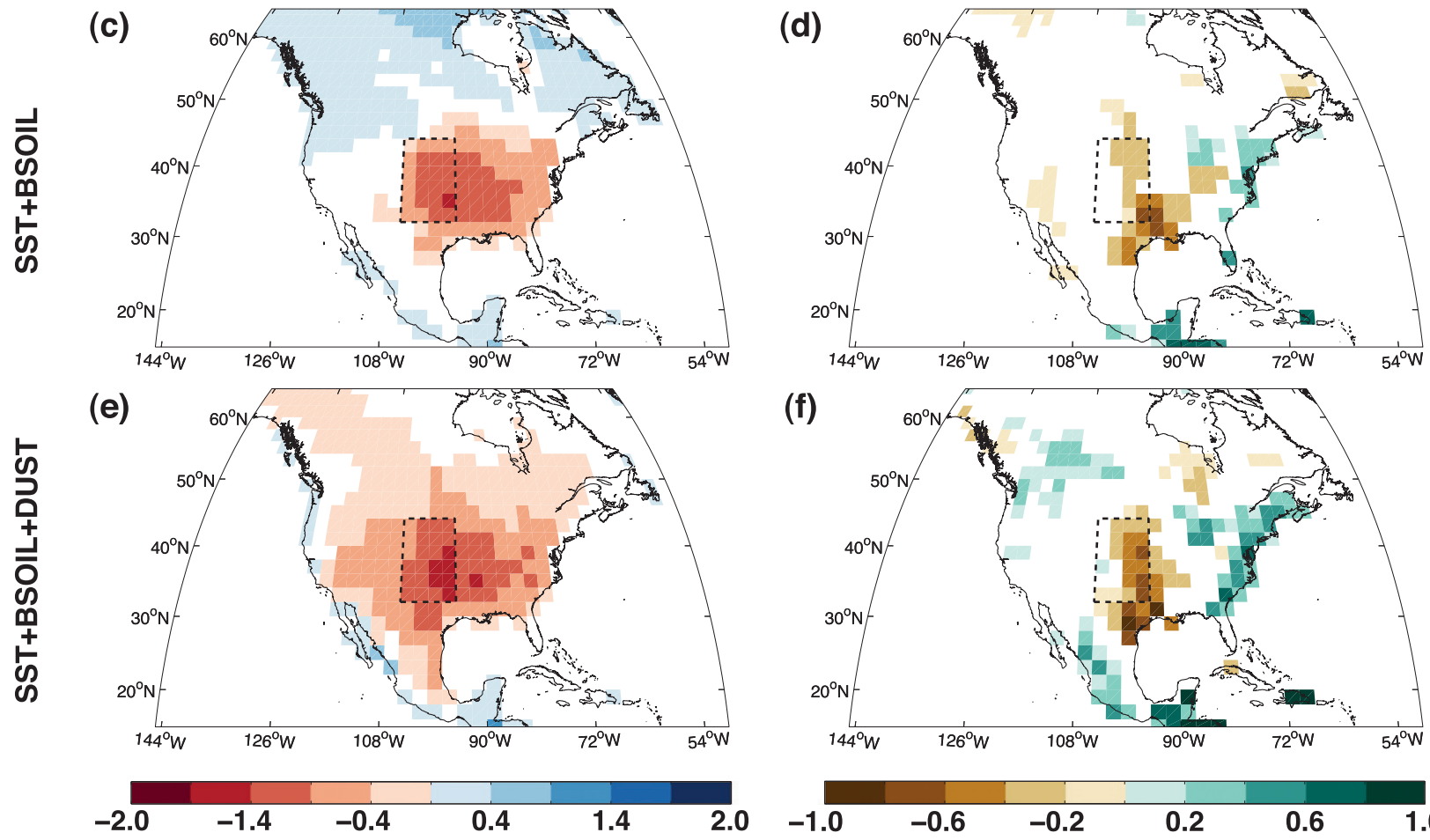

(f)

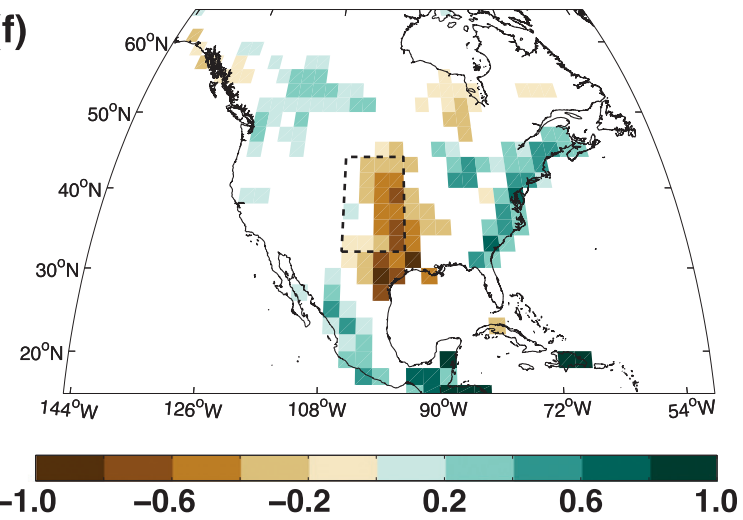

FIG. 7. (a),(c),(e) Ensemble mean monthly surface temperature (JJA; K) and (b),(d),(f) precipitation (June; mm day $^{-1}$ ) anomalies over North America in our MCA model runs. The central plains region $\left(32^{\circ}-44^{\circ} \mathrm{N}, 105^{\circ}-95^{\circ} \mathrm{W}\right)$ is outlined in the black dashes. Cells with insignificant $(p \geq 0.05)$ differences between the MCA runs and SST-MOD have been masked out.

\section{d. Model precipitation and temperature response}

To determine the primary drivers of the PDSI anomalies in the MCA scenarios, we analyzed model precipitation and surface temperature anomalies over the central plains region. All three MCA model scenarios show significantly warmer and drier conditions over the central plains, relative to the SST-MOD ensemble (Fig. 6). In SST-Only (blue bars), these anomalies are largest during summer and fall (June-November). The winter responses in SST-Only are muted and largely insignificant, an expected result because our central plains region is on the northeast edge of the main SSTteleconnection response during this season. This same region does have a small but significant warm season teleconnection with La Niña (Bunkers et al. 1996), and this is reflected in the modest drying during the summer and fall. Notably, our winter and summer precipitation anomalies are similar in magnitude and spatial extent when compared to a recent millennium run of the Community Climate System Model forced with solar, volcanic, and greenhouse gas forcing estimates and a coupled ocean (Landrum et al. 2012). This suggests that the background drying during summer may be, to some extent, forced by changes at the top of the atmosphere during the MCA or other, forced, SST variability.

Warming in SST + BSOIL (green bars) is significantly increased beyond the SST forcing in May-October; dust 

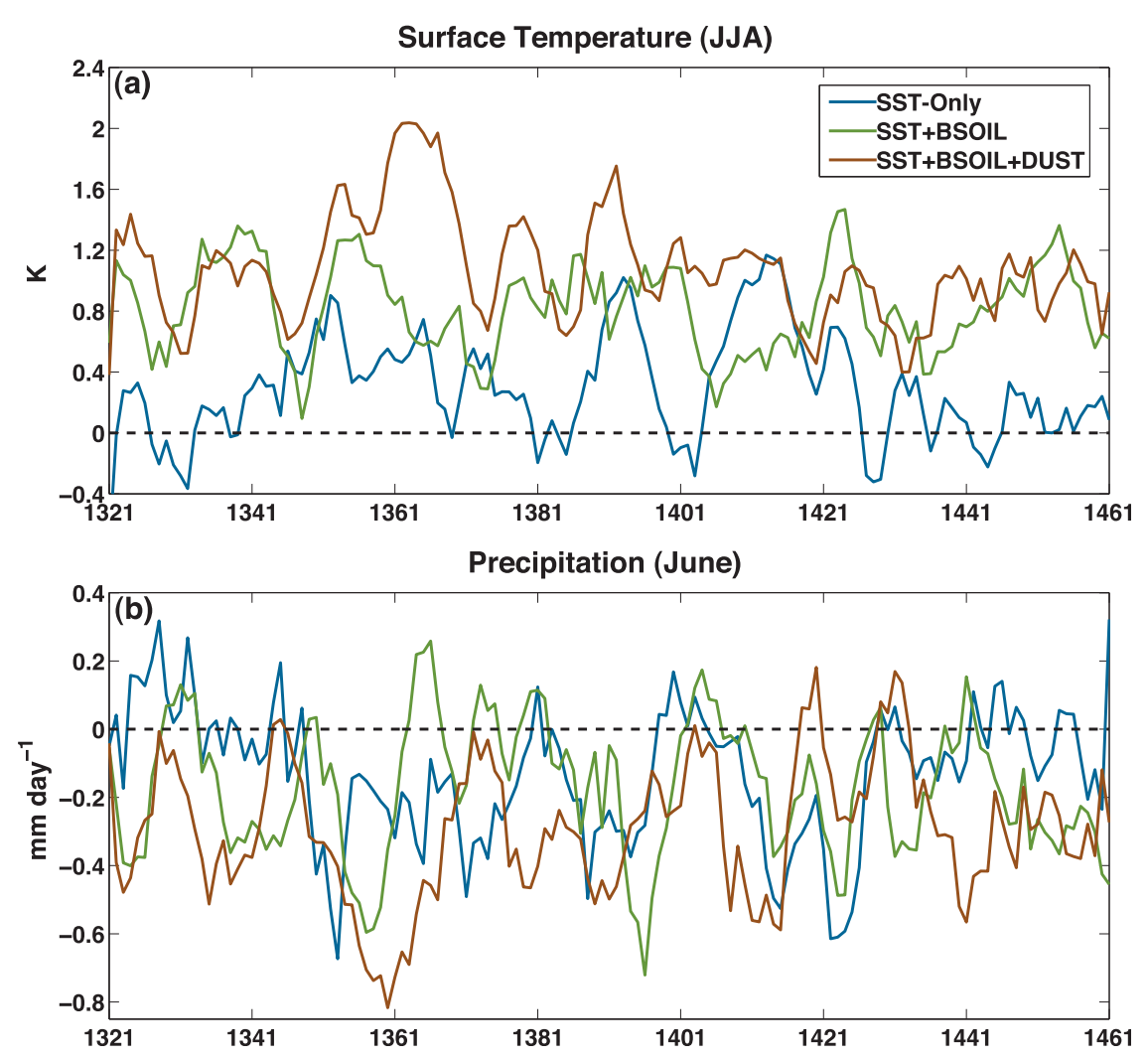

FIG. 8. Ensemble mean time series of (a) mean monthly surface temperature (JJA; K) and (b) precipitation (June; mm day ${ }^{-1}$ ) anomalies over North America in our MCA model runs, averaged over the central plains region $\left(32^{\circ}-44^{\circ} \mathrm{N}, 105^{\circ}-95^{\circ} \mathrm{W}\right)$. All time series have been smoothed with a 5-yr low-pass (lowess) filter.

aerosols in SST+BSOIL+DUST (brown bars) further enhance the warming in March-April and June-August. SST + BSOIL leads to a minor reduction of precipitation during July, but the impact of the increased bare soil on precipitation beyond the SST forcing is insignificant otherwise. Dust aerosol forcing in June, however, causes significant additional precipitation reductions, nearly doubling the precipitation anomaly of SST-Only. In the case of SST+BSOIL+DUST, it therefore appears that the drought amplification indicated by the model PDSI (Fig. 5) is driven primarily by enhanced evapotranspiration from warming during the summer (JJA) and precipitation reductions during June. To isolate and describe the underlying physical mechanisms for the drought amplification, we therefore focus our analyses on the temperature response during JJA and the precipitation response during June.

Spatially, SST-Only shows significant surface warming and drying over the central plains and much of eastern North America (Figs. 7a,b). This warming is enhanced over the central plains in SST+BSOIL (Fig. 7c), but the June precipitation response (Fig. 7d) is similar to SSTOnly. Dust aerosol forcing in SST+BSOIL+DUST further enhances the warming over the central plains (Fig. 7e) and leads to moderate increases in temperature over a wider region. The dust aerosols intensify the drying over the central plains (Fig. 7f) and also lead to some moderate drying in the southern plains and Texas. The wider spatial scale of the climate response to the dust aerosols compared to the change in source extent is likely due to the response to the dust aerosol forcing spreading out spatially over at least a Rossby radius of deformation. All three scenarios show substantial temporal variability in the temperature and precipitation response over the central plains (Fig. 8). Temperatures in SST+BSOIL and SST+BSOIL+DUST are, in general, consistently warmer than SST-Only (Fig. 8a). Qualitatively, summer temperature responses in our MCA simulations are consistent with a recent Midwest temperature reconstruction (Wahl et al. 2012), which also suggests warmer JJA temperatures during the MCA (1100-1500 CE), relative to the Little Ice Age (1500-1900 CE). Mean surface temperatures in SST + BSOIL and SST + BSOIL+DUST are significantly warmer than SST-Only by +0.53 and $+0.79 \mathrm{~K}$, respectively (Fig. 9a). Maximum temperature increases are largest in the SST+BSOIL scenarios (Fig. 9c), 

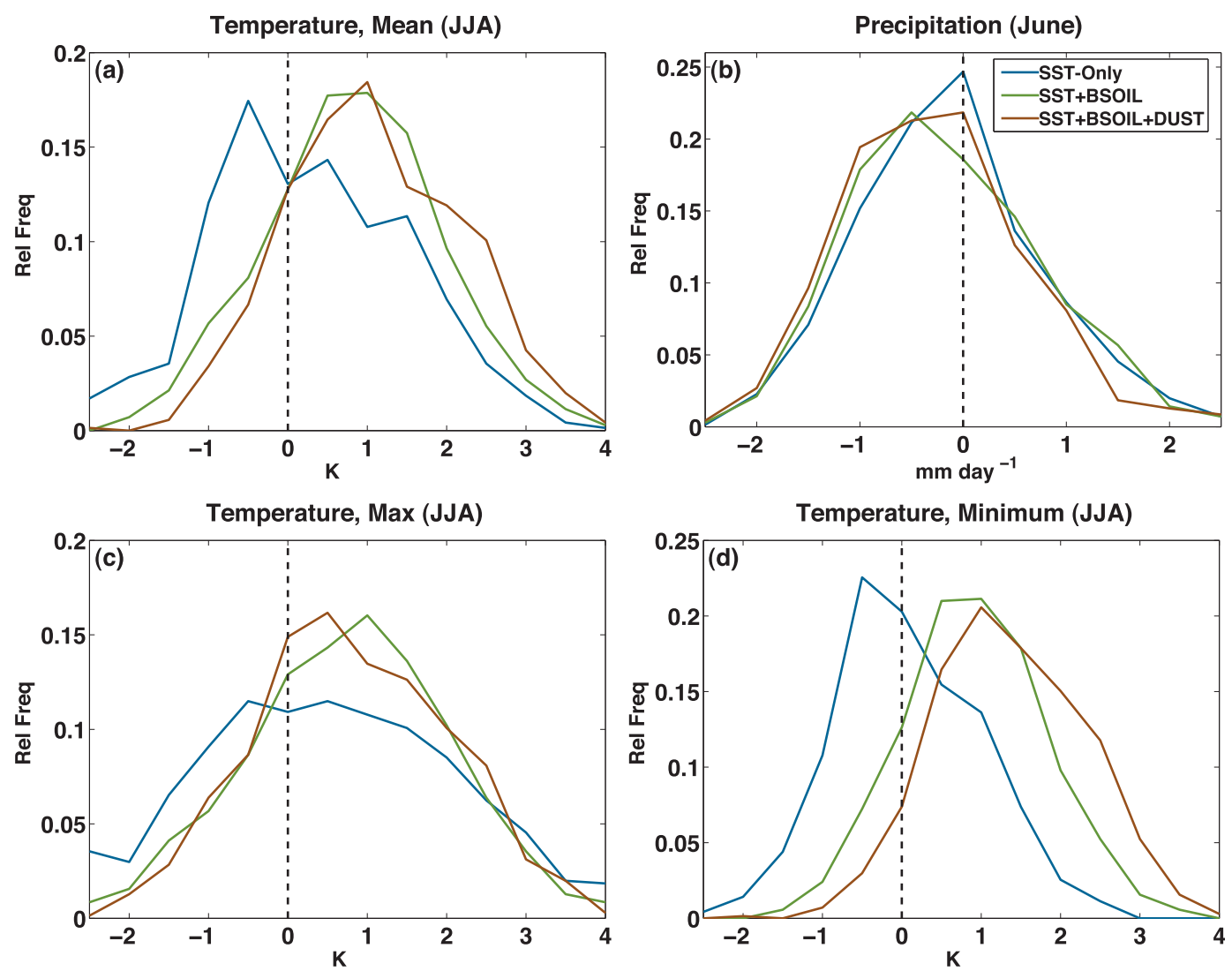

FIG. 9. Normalized histograms of (a) mean monthly surface temperature (JJA, K), (b) precipitation (June, mm day ${ }^{-1}$ ), (c) mean monthly maximum surface temperature (JJA, K), and (d) mean monthly minimum surface temperature (JJA, K) anomalies over North America in our MCA model runs, averaged over the central plains region $\left(32^{\circ}-44^{\circ} \mathrm{N}, 105^{\circ}-95^{\circ} \mathrm{W}\right)$.

but dust aerosol forcing leads to significant increases in minimum temperatures beyond either SST-Only or SST+BSOIL (Fig. 9d) owing to dust inhibition of infrared cooling by the surface at night (see next section). Precipitation in SST + BSOIL+DUST is generally lower than in the other MCA simulations (Fig. 8b), but periods of near-normal precipitation are interspersed with exceptionally dry intervals. The very dry intervals generally coincide with especially cold SST forcing (Fig. 1a) (e.g., 1350-70 CE, 1380-1410 CE), implying that the dust aerosols amplify externally forced drought conditions. Precipitation in SST+BSOIL+DUST during June is significantly suppressed, on average, by an additional $-0.16 \mathrm{~mm}$ day $^{-1}$ over SST-Only; the SST+BSOIL difference is insignificant (Fig. 9b).

\section{e. Surface fluxes (JJA)}

Increases in maximum temperatures are driven primarily by shifts in the surface energy balance from latent (Fig. 10a) to sensible heating (Fig. 10b). Reduced vegetation cover in SST+BSOIL and SST+BSOIL+DUST reduces transpiration, the flux of moisture from the land surface to the atmosphere through the leaves of plants. This leads to an overall decline in evapotranspiration and latent heat flux that is largely balanced by increases in sensible heating. Sensible heat flux anomalies in the SST+BSOIL+DUST experiment are muted compared to SST+BSOIL: the addition of the dust aerosols reduces surface heating through increased shortwave reflection, reducing incident solar inputs at the surface (Fig. 10c). Maximum temperature still increases, however, because the latent heat flux reduction is still large relative to the sensible heat flux anomaly. Because dust aerosols are effective absorbers of infrared radiation, they trap outgoing longwave radiation at night (Fig. 10d), insulating the surface and increasing minimum temperatures (Fig. 9d).

\section{f. Surface responses (June)}

Owing to increases in albedo and shortwave reflection, both SST+BSOIL and SST+BSOIL+DUST have reduced net radiation at the surface (Fig. 11a). For 

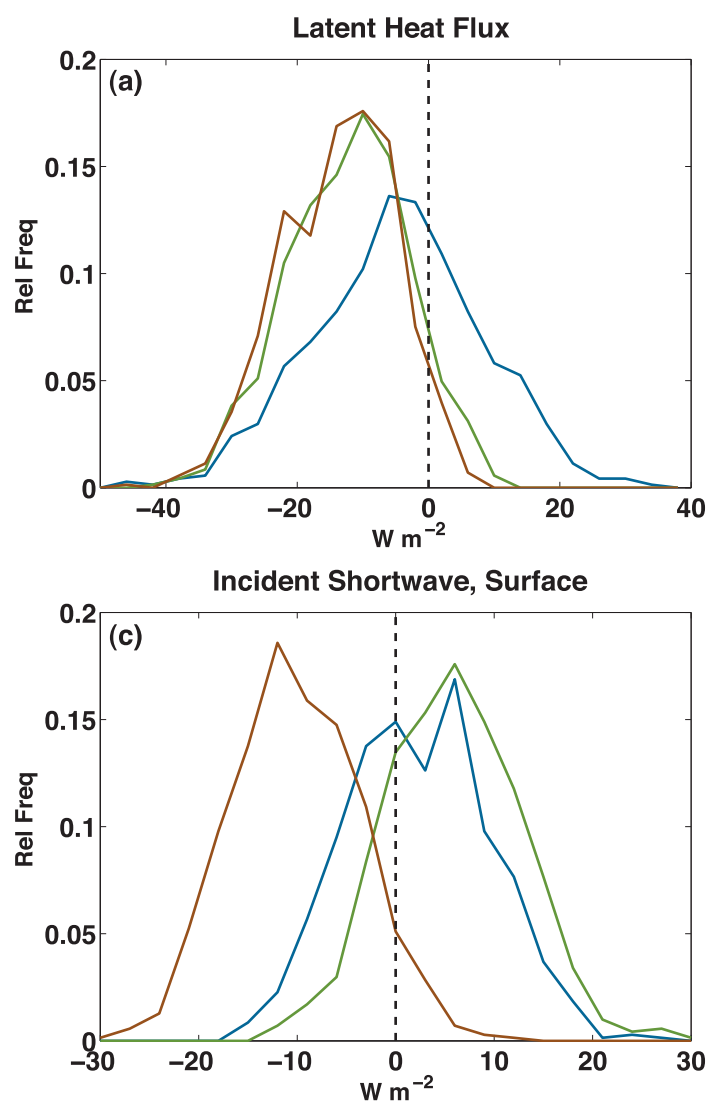

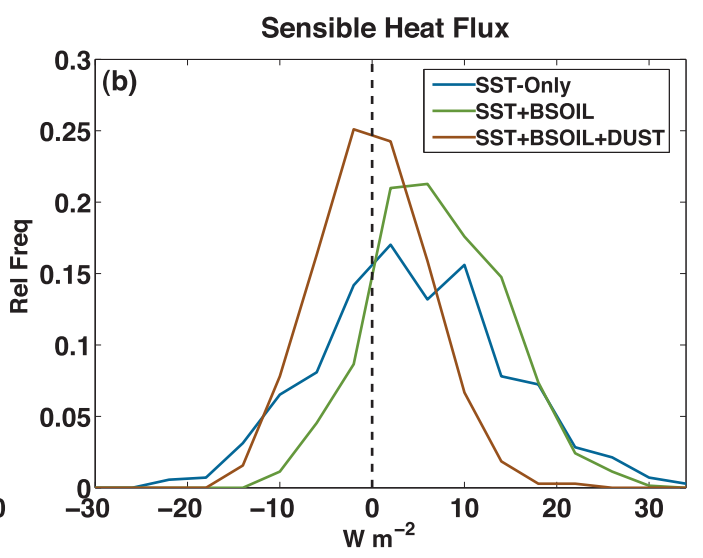

Downwelling Longwave, Surface

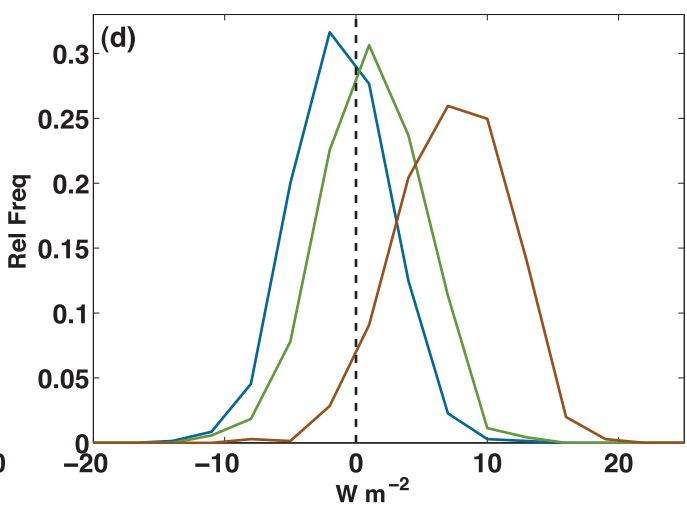

FIG. 10. Normalized histograms of JJA surface flux $\left(\mathrm{W} \mathrm{m}^{-2}\right)$ anomalies averaged over the central plains region $\left(32^{\circ}-44^{\circ} \mathrm{N}, 105^{\circ}-95^{\circ} \mathrm{W}\right)$ : (a) latent heat flux, (b) sensible heat flux, (c) incident shortwave flux at the surface, and (d) downwelling longwave flux at the surface.

SST+BSOIL, the albedo increase comes from the increased bare soil coverage, which tends to have a higher shortwave albedo than vegetation. In SST+BSOIL+ DUST, the albedo increase is from a combination of increased surface albedo from the bare soil and increased shortwave reflection from the dust aerosols. The energy deficit at the surface reduces planetary boundary layer heights (Fig. 11b) and decreases the daytime peak boundary-layer lapse rate (Fig. 11c). The boundary layer responses lead to increased stability, inhibiting vertical motion of air parcels and significantly reducing convective cloud cover (Fig. 11d) and precipitation. The radiative perturbation is only large enough to reduce precipitation beyond SST-Only forcing in the SST+BSOIL+DUST experiment.

\section{g. Drought persistence in the MCA simulations}

Ensemble-mean central plains PDSI time series for JJA are shown in Fig. 12, the same season represented by the NADA. All three model experiments produce recurrent periods of summer drought, but only the SST+BSOIL+DUST ensemble is able to simulate droughts with similar durations to the droughts in the NADA (Fig. 3a). This apparent increased persistence is confirmed by calculating the autocorrelation function of these model PDSI time series (Fig. 13). Based on the unadjusted PDSI (Figs. 13a-c), the SST+BSOIL+ DUST scenario is the only run that simulates significant persistence out to a period of $10 \mathrm{yr}$, although it may be overestimated relative to the NADA. If the PDSI time series are adjusted to a zero mean (Figs. 13d-f), the SST + BSOIL + DUST autocorrelation function aligns quite closely with the NADA function and is the only one of our three MCA scenarios with significant persistence at time lags of 1,2 , and $3 \mathrm{yr}$.

\section{Discussion and conclusions}

Drought is a recurrent and societally relevant climate phenomenon in much of North America, especially in the western half of the continent. From 1980 to 2003, droughts caused $\$ 144$ billion in damages and lost production (Cook et al. 2007; Ross and Lott 2003), accounting for $41 \%$ of the total cost of all weather-related 

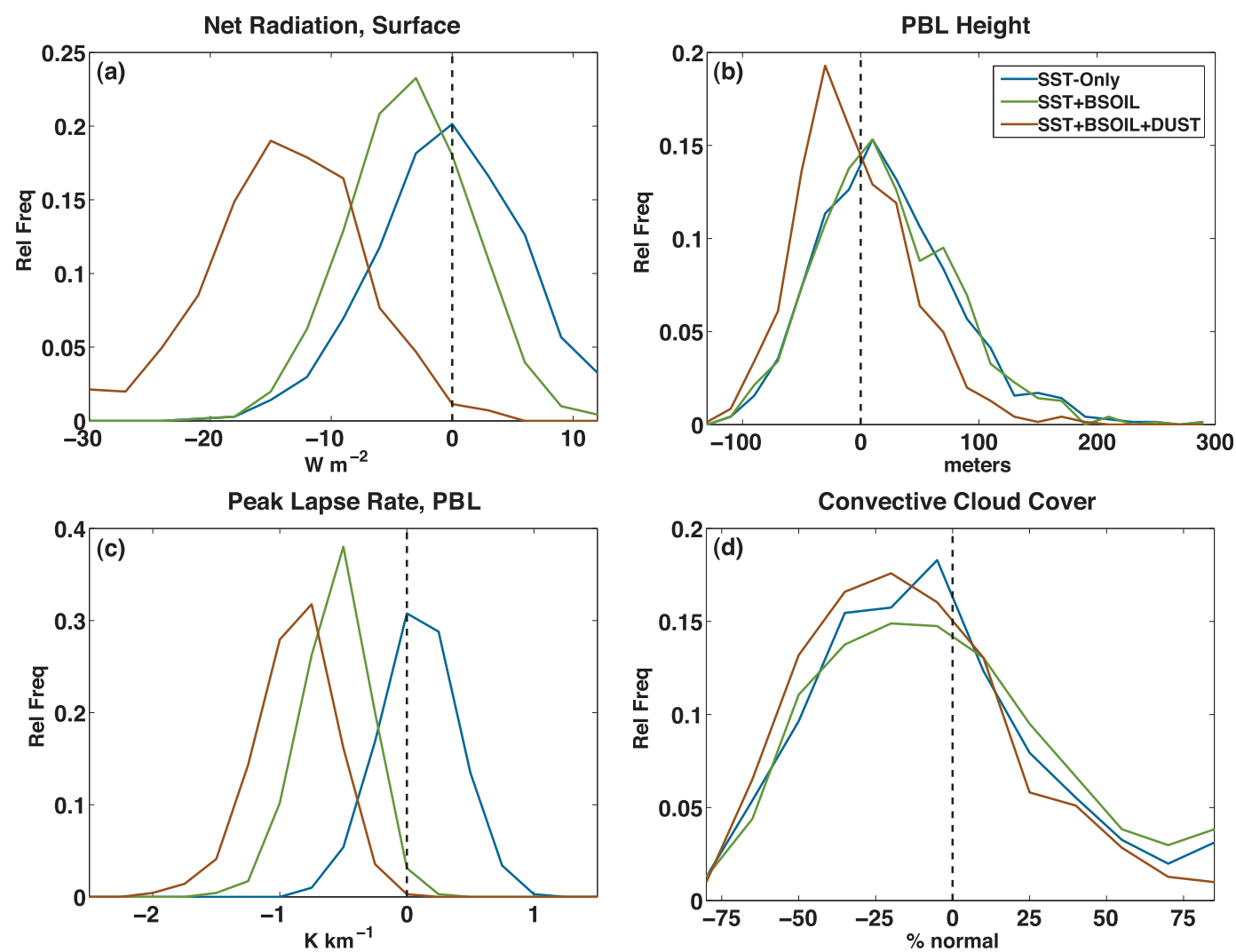

FIG. 11. Normalized histograms of mean June surface climate anomalies averaged over the central plains region $\left(32^{\circ}-44^{\circ} \mathrm{N}, 105^{\circ}-95^{\circ} \mathrm{W}\right)$ : (a) net radiation at the surface $\left(\mathrm{W} \mathrm{m}^{-2}\right)$, (b) planetary boundary layer height $(\mathrm{m})$, (c) peak lapse rate in the planetary boundary layer $\left(\mathrm{K} \mathrm{km}^{-1}\right)$, and (d) convective cloud cover (\% normal departure).

disasters during this period (Ross and Lott 2003). More recently, severe drought and associated heat waves in the southern plains and U. S. Southwest during 2011 caused $\$ 12$ billion in damages and 95 deaths (NCDC 2011). Even while acknowledging the significant costs and disruptions associated with modern droughts, it is important to note that the durations of recent droughts are relatively short compared to the events that occurred during the Medieval Climate Anomaly. With available evidence supporting a trajectory toward a drier mean state in the future (e.g., Seager et al. 2007b), it is worth investigating the causes of the MCA megadroughts and whether these factors will play a role in a potentially drier future.

Our experiments demonstrate that forcing from cold tropical Pacific SSTs and increased bare soil is insufficient to reproduce the mean drying and persistence of the megadroughts over the central plains, as indicated by the PDSI reconstruction. Dust aerosols, however, are able to amplify the drought response in the model by suppressing precipitation, generating model PDSI largely consistent with the PDSI reconstructed in the NADA reconstruction. The ability of our model PDSI to match the persistence of the reconstructed PDSI is especially notable, as this is generally considered the defining characteristic of these MCA megadroughts (Cook et al. 2010).

In the real world, persistence would arise from vegetation mortality caused by dust-induced drying, which would feed back to sustain dune mobilization, wind erosion, and dry conditions. Our model, however, lacks the capability to fully simulate these dynamical interactions. Instead, the persistence appears to arise from interactions between the dust emissions, precipitation, and soil moisture. When precipitation is high, increased soil moisture inhibits wind erosion, reducing dust emissions and the impact of dust aerosols on precipitation, favoring overall wetter conditions. Conversely, when conditions are drier, wind erosion and dust aerosol forcing increases, reducing precipitation and shifting the climate to even drier conditions. This mechanism is supported by instantaneous and lagged correlations between dust emissions (wind erosion) and precipitation over the central plains in our model. At zero lag, dust emissions and precipitation are negatively and significantly $(p \leq 0.05)$ correlated $(r=-0.56)$, indicating 

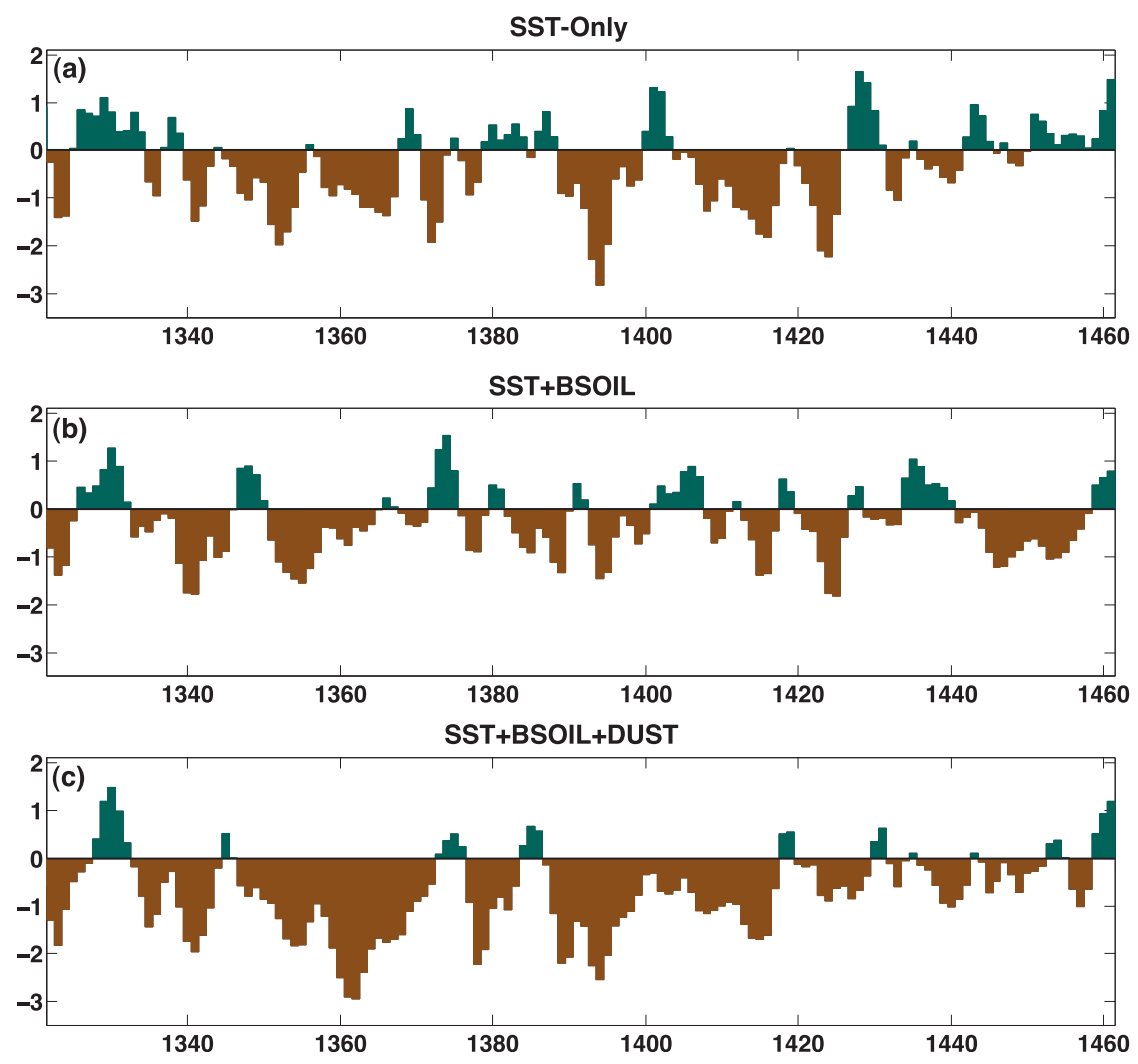

FIG. 12. Ensemble average summer season (JJA) PDSI calculated from our MCA simulations and averaged over the central plains region $\left(32^{\circ}-44^{\circ} \mathrm{N}, 105^{\circ}-95^{\circ} \mathrm{W}\right)$ : (a) SST-Only, (b) SST+BSOIL, and (c) SST+BSOIL+DUST. PDSI anomalies for all MCA runs were normalized relative to 1857-2005 CE from the SST-MOD ensemble.

increased wind erosion and emission of dust with drier conditions. At a lag of $1 \mathrm{yr}$, with precipitation leading dust emissions, the correlation is still significant $(r=$ -0.40 ); higher rainfall in one year will lead to reduced dust emissions in the following year as the land surface memory carries the positive soil moisture anomaly forward in time. The correlation with dust emissions leading precipitation by one year is smaller $(r=-0.17)$, but still significant and negative. A dusty year will inhibit precipitation, making the soils drier. This dry soil moisture anomaly carries forward in time, allowing increased dust emissions that further act to inhibit precipitation the next year.

Our results are promising and support the idea that land surface feedbacks from aeolian activity during the MCA played an important role in reinforcing the megadroughts in the plains. These feedbacks have been hinted at previously in studies of the Dust Bowl (Cook et al. 2008, 2009), the only observational era drought with land degradation and aeolian activity approaching the same scale as the megadroughts. Even more so than for the Dust Bowl, however, large uncertainties remain in both the timing and magnitude of drought forcings during the MCA. Further refinement of the land surface boundary condition estimates, especially the time uncertainties, would allow for better comparisons between the model simulations and specific events. For SSTs, additional proxies from corals or sediment records in the Pacific and Atlantic would help decrease uncertainties and increase the spatial coverage of the SST reconstructions in these basins.

We also note that, due to limitations of ModelE, we were forced to prescribe the land surface changes and dust aerosol source as time-invariant boundary conditions. In the real world, the vegetation, aeolian system, and climate system are tightly coupled, and we would expect the droughts to initiate independently (e.g., from SST forcing), driving the vegetation mortality and wind erosion that would feedback to amplify the original drought. Even with a fully coupled model including dynamic vegetation, however, there would still be uncertainties concerning the time scale of vegetation recovery and mortality and the subsequent stabilization or activation of the dune systems. For example, Mangan 

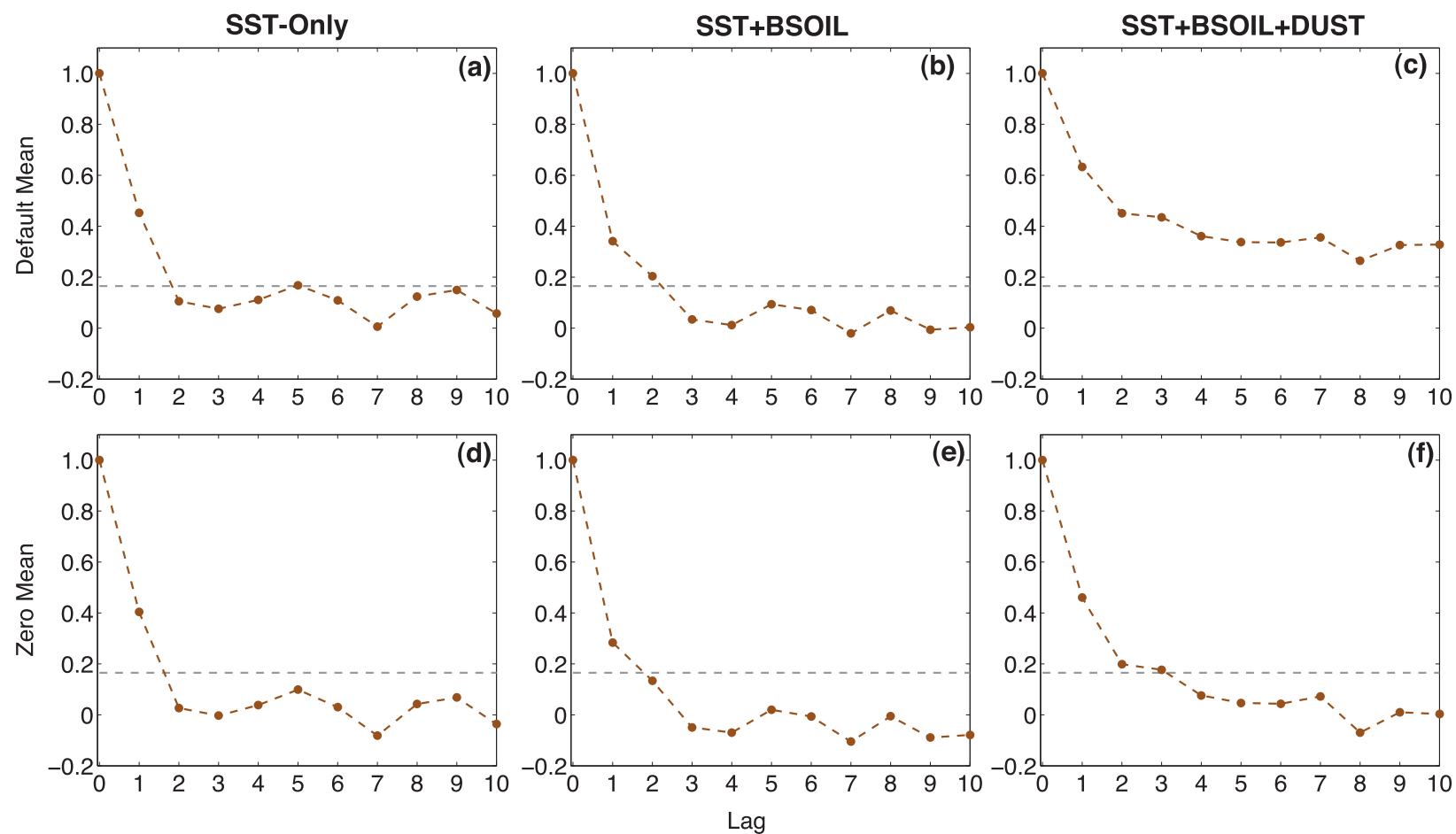

FIG. 13. ACF for the ensemble average JJA central plains PDSI $\left(32^{\circ}-44^{\circ} \mathrm{N}, 105^{\circ}-95^{\circ} \mathrm{W}\right)$ from the (a) SST-Only, (b) SST + BSOIL, and (c) SST+BSOIL+DUST model runs. PDSI in the SST+BSOIL+DUST ensemble, driven by the dust aerosol-forced drying, is the only scenario that can generate significant persistence at time scales similar to the MCA PDSI from the NADA. (d),(e),(f) Even after the adjustment to zero mean, SST+BSOIL+DUST is the only the scenario with significant persistence at lags of 2 and $3 \mathrm{yr}$, similar to the autocorrelation of the adjusted NADA PDSI.

et al. (2004) used a model of nutrient cycling and ecosystem dynamics to demonstrate that vegetation on dune systems can respond rapidly to interannual precipitation changes. Conversely, geomorphological studies suggest that vegetation recovery and dune stabilization may take decades to a century or more in some regions (Hugenholtz and Wolfe 2005; Wolfe and Hugenholtz 2009). Interestingly, the major reduction in precipitation (June) and increase in drought intensity (JJA) in our SST+BSOIL+DUST ensemble occurs during what would be the primary growing season for the warm season grasses that populate the central plains. The timing of the drying in our forced runs is therefore consistent with the drying that would be needed to drive the vegetation mortality and land degradation response in a coupled model. Accurately simulating the time scale of these interactions is a critical modeling challenge and will be necessary in order to estimate the full capacity of dune and vegetation feedbacks to amplify and sustain droughts in this region.

Our experiments provide support for the idea that surface factors, especially the dust aerosols, can explain the persistence of the medieval megadroughts over the central plains. Regions outside the central plains also experienced persistent megadroughts during the MCA, but with no evidence for additional forcing from local land degradation. Examples include megadroughts that occurred in California (Cook et al. 2010; Stine 1994), Colorado (Gray et al. 2011; Meko et al. 2007; Routson et al. 2011), and the U. S. Southwest (Woodhouse et al. 2010) and some droughts with a near-continental scale (Herweijer et al. 2007; Stahle et al. 2007). While our study provides support for the importance of the land surface and dust aerosols during the central plains megadroughts, we do not suggest that this is an important feedback in, for example, the Southwest. Instead, it is likely that the relative roles of ocean forcing, atmospheric variability, and land surface feedbacks in generating megadroughts vary across the continent.

In the short term, the land surface dynamics that amplified the megadroughts and Dust Bowl are unlikely to play a major role in the intensification of future droughts. During the Dust Bowl, much of the dust storm activity originated from small farms with few erosion control measures and annual crops that were extremely vulnerable to moisture deficits. The initiation of this drought, forced by cold SSTs in the tropical Pacific (Schubert et al. 2004; Seager et al. 2008b), caused widespread crop failures over the central and southern plains, exposing highly erodible top soil. In response, the 
U. S. government formed the Soil Conservation Service with the goal of preventing the same level of land degradation from occurring again (Hansen and Libecap 2004) and subsequent droughts (e.g., 1948-57, 19982004) avoided the same levels of wind erosion and dust storm activity, despite severe moisture deficits. Besides erosion measures, irrigation in the west has also expanded rapidly since the 1950s (Wisser et al. 2010), providing additional sources of water that have enabled farmers to be more resistant to drought events. Other than farmlands, much of the region is composed of pastures and grasslands that host perennial grasses evolutionarily adapted to the hydroclimatic variability in the region and capable of surviving at least short-term droughts. There is evidence, though, that grasslands in some regions will degrade in response to longer-term droughts (Evans et al. 2011) and that livestock grazing activities may make these systems more vulnerable (Van Auken 2000). As the twenty-first century progresses, various factors will affect the resilience of agricultural and natural systems in the region, and the potential for landscape feedbacks to drought. On one side, both greenhouse-gas-forced drying trends (Seager et al. 2007b) and the continued depletion of nonrenewable groundwater resources (e.g., Sophocleous 2010) will increase drought stress on natural ecosystems and agricultural systems. Conversely, the direct effect of increased atmospheric carbon dioxide concentrations on plant physiology may serve to actually increase plant resistance to water stress and drought (e.g., Morgan et al. 2011). The future of hydroclimate and landscape processes in the central plains and western North America will thus likely depend on the complex interplay of climate dynamics, ecosystem responses, and direct human management.

Acknowledgments. Resources supporting this work were provided by the National Aeronautics and Space Administration (NASA) High-End Computing (HEC) Program through the NASA Center for Climate Simulation (NCCS) at Goddard Space Flight Center. The authors acknowledge the support of NSF Grant ATMO9-02716; NOAA Grant NA100AR-4310137; NSF Grant ATM-06-20066; the NASA Atmospheric Composition Program; and the NASA Modeling, Analysis and Prediction (MAP) Program. Jonathan Overpeck and one anonymous reviewer provided feedback that greatly improved the quality of this manuscript.

\section{REFERENCES}

Ball, J. T., I. E. Woodrow, and J. A. Berry, 1987: A model predicting stomatal conductance and its application to the control of photosynthesis under different environmental conditions.
Progress in Photosynthesis, I. Biggins, Ed., Martinus Nijhoff Publishers, 221-224.

Benson, L. V., M. S. Berry, E. A. Jolie, J. D. Spangler, D. W. Stahle, and E. M. Hattori, 2007a: Possible impacts of early-11th-, middle-12th-, and late-13th-century droughts on western $\mathrm{Na}$ tive Americans and the Mississippian Cahokians. Quat. Sci. Rev., 26 (3-4), 336-350.

— K. Petersen, and J. Stein, 2007b: Anasazi (pre-Columbian Native-American) migrations during the middle-12th and late-13th centuries-Were they drought induced? Climatic Change, 83, 187-213.

Bunkers, M. J., J. R. Miller Jr., and A. T. DeGaetano, 1996: An examination of El Niño-La Niña-related precipitation and temperature anomalies across the northern Plains. J. Climate, 9, 147-160.

Burgman, R., R. Seager, A. Clement, and C. Herweijer, 2010: Role of tropical Pacific SSTs in global medieval hydroclimate: A modeling study. Geophys. Res. Lett., 37, L06705, doi:10.1029/ 2009GL042239.

Charney, J. G., 1975: Dynamics of deserts and drought in the Sahel. Quart. J. Roy. Meteor. Soc., 101, 193-202.

_ W. W. Quirk, S. H. Chow, and J. Kornfield, 1977: A comparative study of the effects of albedo change on drought in semiarid regions. J. Atmos. Sci., 34, 1366-1385.

Cobb, K. M., C. D. Charles, H. Cheng, and R. L. Edwards, 2003: El Niño/Southern Oscillation and tropical Pacific climate during the last millennium. Nature, 424, 271-276.

Conroy, J. L., J. T. Overpeck, J. E. Cole, and M. Steinitz-Kannan, 2009a: Variable oceanic influences on western North American drought over the last 1200 years. Geophys. Res. Lett., 36, L17703, doi:10.1029/2009GL039558.

— A. Restrepo, J. T. Overpeck, M. Steinitz-Kannan, J. E. Cole, M. B. Bush, and P. A. Colinvaux, 2009b: Unprecedented recent warming of surface temperatures in the eastern tropical Pacific Ocean. Nat. Geosci., 2, 46-50, doi:10.1038/ngeo390.

Cook, B. I., R. L. Miller, and R. Seager, 2008: Dust and sea surface temperature forcing of the 1930s "Dust Bowl"drought. Geophys. Res. Lett., 35, L08710, doi:10.1029/2008GL033486.

,$- \ldots$, and -2009 : Amplification of the North American "Dust Bowl" drought through human-induced land degradation. Proc. Natl. Acad. Sci. USA, 106, 4997-5001.

_ R. Seager, and R. L. Miller, 2011: The impact of devegetated dune fields on North American climate during the late Medieval Climate Anomaly. Geophys. Res. Lett., 38, L14704, doi:10.1029/2011GL047566.

Cook, E. R., C. A. Woodhouse, C. M. Eakin, D. M. Meko, and D. W. Stahle, 2004: Long-term aridity changes in the western United States. Science, 306, 1015-1018.

—, R. Seager, M. A. Cane, and D. W. Stahle, 2007: North American drought: Reconstructions, causes, and consequences. Earth Sci. Rev., 81 (1-2), 93-134.

,-- , R. R. Heim Jr., R. S. Vose, C. Herweijer, and C. Woodhouse, 2010: Megadroughts in North America: Placing IPCC projections of hydroclimatic change in a longterm palaeoclimate context. J. Quat. Sci., 25, 48-61.

Delaygue, G., and E. Bard, 2011: An Antarctic view of beryllium10 and solar activity for the past millennium. Climate Dyn., 36, 2201-2218, doi:10.1007/s00382-010-0795-1.

Douglass, A., 1929: The secret of the southwest solved by talkative tree rings. Natl. Geogr. Mag., 56, 736-770.

Evans, S. E., K. M. Byrne, W. K. Lauenroth, and I. C. Burke, 2011: Defining the limit to resistance in a drought-tolerant grassland: Long-term severe drought significantly reduces the dominant 
species and increases ruderals. J. Ecol., 99, 1500-1507, doi:10.1111/j.1365-2745.2011.01864.x.

Farquhar, G. D., S. Caemmerer, and J. A. Berry, 1980: A biochemical model of photosynthetic $\mathrm{CO}_{2}$ assimilation in leaves of C3 species. Planta, 149, 78-90.

Feng, S., R. J. Oglesby, C. M. Rowe, D. B. Loope, and Q. Hu, 2008: Atlantic and Pacific SST influences on medieval drought in North America simulated by the Community Atmospheric Model. J. Geophys. Res., 113, D11101, doi:10.1029/ 2007JD009347.

Findell, K. L., P. Gentine, B. R. Lintner, and C. Kerr, 2011: Probability of afternoon precipitation in eastern United States and Mexico enhanced by high evaporation. Nat. Geosci., 4, 434-439.

Forman, S. L., R. Oglesby, and R. S. Webb, 2001: Temporal and spatial patterns of Holocene dune activity on the Great Plains of North America: Megadroughts and climate links. Global Planet. Change, 29 (1-2), 1-29.

Ginoux, P., M. Chin, I. Tegen, J. M. Prospero, B. Holben, O. Dubovik, and S. J. Lin, 2001: Sources and distributions of dust aerosols simulated with the GOCART model J. Geophys. Res., 106, 20 255-20273.

Graham, N. E., and Coauthors, 2007: Tropical Pacific-mid-latitude teleconnections in medieval times. Climatic Change, 83, 241285, doi:10.1007/s10584-007-9239-2.

- C. M. Ammann, D. Fleitmann, K. M. Cobb, and J. Luterbacher, 2011: Support for global climate reorganization during the "Medieval Climate Anomaly." Climate Dyn., 37, 1217-1245, doi:10.1007/s00382-010-0914-z.

Gray, S. T., J. J. Lukas, and C. A. Woodhouse, 2011: Millenniallength records of streamflow from three major upper Colorado River tributaries. J. Amer. Water Res. Assoc., 47, 702-712, doi:10.1111/j.1752-1688.2011.00535.x.

Guttman, N. B., 1998: Comparing the Palmer drought index and the standardized precipitation index. J. Amer. Water Resour. Assoc., 34, 113-121.

Hansen, J., and M. Sato, 2004: Greenhouse gas growth rates. Proc. Nat. Acad. Sci. USA, 101, 16109-16114, doi:10.1073/ pnas.0406982101.

— - and Coauthors, 2002: Climate forcings in Goddard Institute for Space Studies SI2000 simulations. J. Geophys. Res., 107, 4347, doi:10.1029/2001JD001143.

_- and Coauthors, 2007: Climate simulations for 1880-2003 with GISS ModelE. Climate Dyn., 29, 661-696.

Hansen, Z. K., and G. D. Libecap, 2004: Small farms, externalities, and the Dust Bowl of the 1930s. J. Polit. Econ., 112, 665694.

Hanson, P. R., A. F. Arbogast, W. C. Johnson, R. Joeckel, and A. Young, 2010: Megadroughts and late Holocene dune activation at the eastern margin of the Great Plains, north-central Kansas, USA. Aeolian Res., 1 (3-4), 101-110.

Herweijer, C., R. Seager, and E. R. Cook, 2006: North American droughts of the mid to late nineteenth century: A history, simulation and implication for mediaeval drought. Holocene, 16, 159-171.

- $-\longrightarrow$, , and J. Emile-Geay, 2007: North American droughts of the last millennium from a gridded network of tree-ring data. J. Climate, 20, 1353-1376.

Hugenholtz, C. H., and S. A. Wolfe, 2005: Recent stabilization of active sand dunes on the Canadian prairies and relation to recent climate variations. Geomorphology, 68, 131-147.

Jacobs, P. M., and J. A. Mason, 2007: Late quaternary climate change, loess sedimentation, and soil profile development in the central Great Plains: A pedosedimentary model. Geol. Soc. Amer. Bull., 119 (3-4), 462-475.

Kaplan, A., M. A. Cane, Y. Kushnir, A. C. Clement, M. B. Blumenthal, and B. Rajagopalan, 1998: Analyses of global sea surface temperature 1856-1991. J. Geophys. Res., 103, 18567-18589.

Koster, R. D., and Coauthors, 2004: Regions of strong coupling between soil moisture and precipitation. Science, 305, 11381141.

Kushnir, Y., R. Seager, M. Ting, N. Naik, and J. Nakamura, 2010: Mechanisms of tropical Atlantic SST influence on North American hydroclimate variability. J. Climate, 23, 5610-5628.

Landrum, L., B. Otto-Bliesner, E. R. Wahl, A. Conley, P. J. Lawrence, and H. Teng, 2012: Last millennium climate and its variability in CCSM4. J. Climate, 25, 4817-4838.

Mangan, J. M., J. T. Overpeck, R. S. Webb, C. Wessman, and A. F. H. Goetz, 2004: Response of Nebraska Sand Hills natural vegetation to drought, fire, grazing, and plant functional type shifts as simulated by the CENTURY model. Climatic Change, 63, 49-90.

Mason, J. A., J. B. Swinehart, R. J. Goble, and D. B. Loope, 2004: Late-Holocene dune activity linked to hydrological drought, Nebraska Sand Hills, USA. Holocene, 14, 209-217.

Matthews, E., 1983: Global vegetation and land use: New highresolution databases for climate studies. J. Climate Appl. Meteor., 22, 474-487.

Meko, D. M., C. A. Woodhouse, C. A. Baisan, T. Knight, J. J. Lukas, M. K. Hughes, and M. W. Salzer, 2007: Medieval drought in the upper Colorado River basin. Geophys. Res. Lett., 34, L10705, doi:10.1029/2007GL029988.

Meng, L., and S. M. Quiring, 2010: Observational relationship of sea surface temperatures and precedent soil moisture with summer precipitation in the US Great Plains. Int. J. Climatol., 30, 884-893.

Miao, X., J. A. Mason, J. B. Swinehart, D. B. Loope, P. R. Hanson, R. J. Goble, and X. Liu, 2007: A 10,000 year record of dune activity, dust storms, and severe drought in the central Great Plains. Geology, 35, 119-122.

Miller, R. L., and Coauthors, 2006: Mineral dust aerosols in the NASA Goddard Institute for Space Sciences ModelE atmospheric general circulation model. J. Geophys. Res., 111, doi:10.1029/2005JD005796.

Mitchell, T. D., and P. D. Jones, 2005: An improved method of constructing a database of monthly climate observations and associated high-resolution grids. Int. J. Climatol., 25, 693-712.

Morgan, J. A., and Coauthors, 2011: C4 grasses prosper as carbon dioxide eliminates desiccation in warmed semi-arid grassland. Nature, 476, 202-205.

Moy, C. M., G. O. Seltzer, D. T. Rodbell, and D. M. Anderson, 2002: Variability of El Niño/Southern Oscillation activity at millennial timescales during the Holocene epoch. Nature, 420, 162-165, doi:10.1038/nature01194.

Muhs, D. R., and P. B. Maat, 1993: The potential response of eolian sands to greenhouse warming and precipitation reduction on the Great Plains of the U.S.A. J. Arid Environ., 25, 351-361.

NCDC, 2011: Billion dollar U.S. weather/climate disasters 19802011. National Climatic Data Center Tech. Rep., 6 pp. [Available online at http://www.ncdc.noaa.gov/billions/events. pdf.]

Newton, A., R. Thunell, and L. Stott, 2006: Climate and hydrographic variability in the Indo-Pacific warm pool during the last millennium. Geophys. Res. Lett., 33, L19710, doi:10.1029/ 2006GL027234. 
Nigam, S., B. Guan, and A. Ruiz-Barradas, 2011: Key role of the Atlantic multidecadal oscillation in 20th century drought and wet periods over the Great Plains. Geophys. Res. Lett., 38, L16713, doi:10.1029/2011GL048650.

Oglesby, R., S. Feng, Q. Hu, and C. Rowe, 2012: The role of the Atlantic multidecadal oscillation on medieval drought in North America: Synthesizing results from proxy data and climate models. Global Planet. Change, 84-85, 56-65, doi:10.1016/j.gloplacha.2011.07.005.

Palmer, W., 1965: Meteorological drought. U.S. Weather Bureau Research Paper 45, 58 pp.

Ross, T., and N. Lott, 2003: A climatology of 1980-2003 extreme weather and climate events. NOAA/NESDIS/National Climatic Data Center Tech. Rep., 14 pp.

Routson, C. C., C. A. Woodhouse, and J. T. Overpeck, 2011: Second century megadrought in the Rio Grande headwaters, Colorado: How unusual was medieval drought? Geophys. Res. Lett., 38, L22703, doi:10.1029/2011GL050015.

Ruiz-Barradas, A., and S. Nigam, 2006: IPCC's twentieth-century climate simulations: Varied representations of North American hydroclimate variability. J. Climate, 19, 4041-4058.

Sato, M., J. E. Hansen, M. P. McCormick, and J. B. Pollack, 1993: Stratospheric aerosol optical depths, 1850-1990. J. Geophys. Res., 98, 22 987-22994.

Schmidt, G. A., and Coauthors, 2006: Present-day atmospheric simulations using GISS ModelE: Comparison to in situ, satellite, and reanalysis data. J. Climate, 19, 153-192.

_- and Coauthors, 2011: Climate forcing reconstructions for use in PMIP simulations of the last millennium (v1.0). Geosci. Model Dev. 4, 33-45, doi:10.5194/gmd-4-33-2011.

Schubert, S. D., M. J. Suarez, P. J. Pegion, R. D. Koster, and J. T. Bacmeister, 2004: On the cause of the 1930s Dust Bowl. Science, 303, 1855-1859.

—_, and Coauthors, 2009: A U.S. CLIVAR project to assess and compare the responses of global climate models to droughtrelated SST forcing patterns: Overview and results. J. Climate, 22, 5251-5272.

Seager, R., Y. Kushnir, C. Herweijer, N. Naik, and J. Velez, 2005: Modeling of tropical forcing of persistent droughts and pluvials over western North America: 1856-2000. J. Climate, 18, 4065-4088.

—, N. Graham, C. Herweijer, A. L. Gordon, Y. Kushnir, and E. Cook, 2007a: Blueprints for medieval hydroclimate. Quat. Sci. Rev., 26 (19-21), 2322-2336.

— transition to a more arid climate in southwestern North America. Science, 316, 1181-1184, doi:10.1126/science.1139601. , R. Burgman, Y. Kushnir, A. Clement, E. Cook, N. Naik, and J. Miller, 2008a: Tropical Pacific forcing of North American medieval megadroughts: Testing the concept with an atmosphere model forced by coral-reconstructed SSTs. J. Climate, 21, 6175-6190.

_- Y. Kushnir, M. Ting, M. Cane, N. Naik, and J. Miller, 2008b: Would advance knowledge of 1930s SSTs have allowed prediction of the Dust Bowl drought? J. Climate, 21, 3261-3281.

Sophocleous, M., 2010: Review: Groundwater management practices, challenges, and innovations in the high plains aquifer, USA-Lessons and recommended actions. Hydrogeol. J., 18, 559-575.

Stahle, D. W., F. K. Fye, E. R. Cook, and R. D. Griffin, 2007: Treering reconstructed megadroughts over North America since AD 1300. Climatic Change, 83, 133-149.

Stine, S., 1994: Extreme and persistent drought in California and Patagonia during mediaeval time. Nature, 369, 546-549, doi:10.1038/369546a0.

Thompson, L. G., E. Mosley-Thompson, and B. M. Arnao, 1984: El Niño-Southern Oscillation events recorded in the stratigraphy of the tropical Quelccaya Ice Cap, Peru. Science, 226, 50-53, doi:10.1126/science.226.4670.50.

Thornthwaite, C., 1948: An approach toward a rational classification of climate. Geogr. Rev., 38, 55-94.

Van Auken, O. W., 2000: Shrub invasions of North American semiarid grasslands. Annu. Rev. Ecol. Syst., 31, 197-215.

Vicente-Serrano, S. M., S. Beguería, J. I. López-Moreno, M. Angulo, and A. El Kenawy, 2010: A new global 0.5 gridded dataset (1901-2006) of a multiscalar drought index: Comparison with current drought index datasets based on the Palmer drought severity index. J. Hydrometeor., 11, 1033-1043.

Wahl, E. R., H. F. Diaz, and C. Ohlwein, 2012: A pollen-based reconstruction of summer temperature in central North America and implications for circulation patterns during medieval times. Global Planet. Change, 84-85, 66-74, doi:10.1016/ j.gloplacha.2011.10.005.

Wang, Y.-M., J. L. Lean, and J. N. R. Sheeley, 2005: Modeling the sun's magnetic field and irradiance since 1713. Astrophys. J., 625, 522, doi: $10.1086 / 429689$.

Wisser, D., B. M. Fekete, C. J. Vorosmarty, and A. Schumann, 2010: Reconstructing 20th century global hydrography: A contribution to the Global Terrestrial Network-Hydrology (GTN-H). Hydrol. Earth Syst. Sci., 14, 1-24.

Wolfe, S. A., and C. H. Hugenholtz, 2009: Barchan dunes stabilized under recent climate warming on the northern Great Plains. Geology, 37, 1039-1042.

Woodhouse, C. A., and J. T. Overpeck, 1998: 2000 years of drought variability in the central United States. Bull. Amer. Meteor. Soc., 79, 2693-2714.

_ D. M. Meko, G. M. MacDonald, D. W. Stahle, and E. R. Cook, 2010: A 1,200-year perspective of 21st century drought in southwestern North America. Proc. Nat. Acad. Sci. USA, 107, 21 283-21288, doi:10.1073/pnas.0911197107. 